\title{
Curcumin Analogues as the Inhibitors of TLR4 Pathway in Inflammation and Their Drug
}

\section{Like Potentialities: A Computer-based Study}

Md. Asad Ullah ${ }^{1}$, Fatema Tuz Johora ${ }^{1}$, Bishajit Sarkar $^{1}$, Yusha Araf ${ }^{2}$, MD. Hasanur Rahman ${ }^{3}$

${ }^{1}$ Department of Biotechnology and Genetic Engineering, Faculty of Biological Sciences, Jahangirnagar University, Dhaka, Bangladesh

${ }^{2}$ Department of Genetic Engineering and Biotechnology, Faculty of Life Sciences, Shahjalal University of Science and Technology, Sylhet, Bangladesh

${ }^{3}$ Department of Biotechnology and Genetic Engineering, Bangabandhu Sheikh Mujibur Rahman Science and Technology University, Faculty of Life Sciences, Gopalganj, Bangladesh

*Correspondence: ullah1194@gmail.com 


\begin{abstract}
In this study Curcumin and their different analogues have been analyzed as the inhibitors of signaling proteins i.e., Cycloxygenase-2 (COX-2), Inhibitor of Kappa $\beta$ Kinase (IKK) and TANK binding kinase-1 (TBK-1) of Toll Like Receptor 4 (TLR4) pathway involved in inflammation using computational tools. Multiple analogues showed better binding affinity than the approved drugs for the respective targets. Upon continuous computational exploration 6-Gingerol, Yakuchinone A and Yakuchinone B were identified as the best inhibitors of COX-2, IKK and TBK-1 respectively. Then their drug like potentialities were analyzed in different experiments where they also performed sound and similar. Hopefully, this study will uphold the efforts of researchers to identify anti-inflammatory drugs from natural sources.
\end{abstract}

Keywords: Anti-inflammatory; Curcumin; Inflammation, Inhibitor, TLR4 


\section{Introduction}

Inflammation is delineated as normal biological as well as immune response against harmful stimuli including pathogens (bacteria, virus), toxins, stress, radiation, damaged cells etc. It is one of the protective mechanism of an organism to vanish invading stimulation, wound healing and for the restoration body's normal physiology [1][2]. Inflammation is the result of several biological processes. Tissue injury or infection triggers inflammation as well as subsequent inflammatory cascade. Typical inflammatory cascade consists of four components (Figure 1).

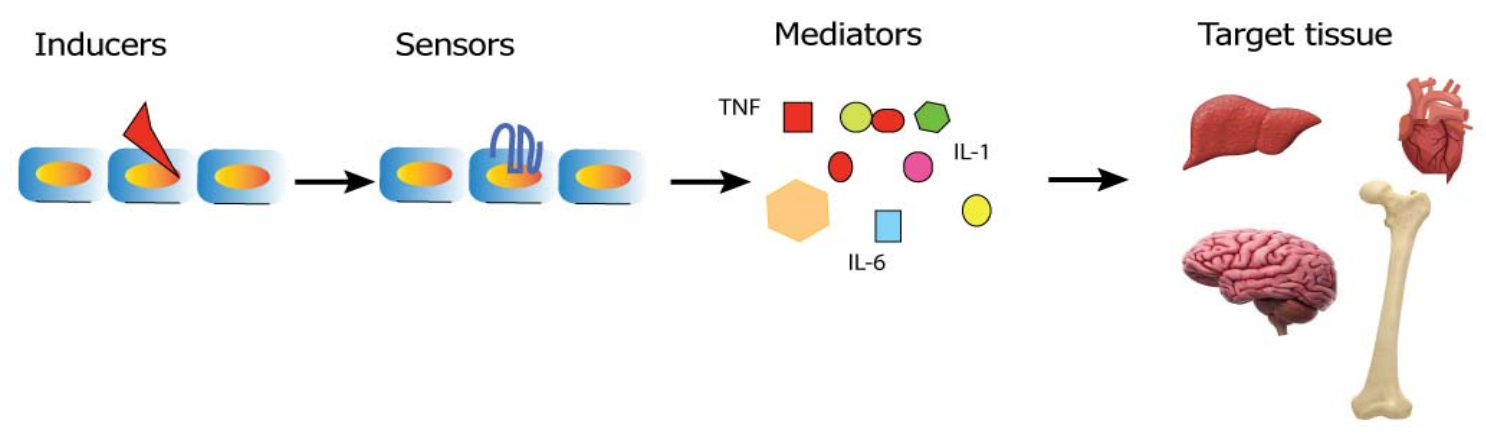

Figure 1: Components of inflammatory cascade. Inducers activate the sensors that results in the release of inflammatory mediators and then inflammatory mediators carry out the events that result in inflammation in target tissue.

(i). Inducers: Exogenous immune inducers (pathogens, virus, bacteria, allergens etc.) or endogenous inducers (damaged cells, stress) results in infection. (ii). Sensors: Specific receptors i.e., toll like receptors (sensors) recognize these inducers. These receptors are localized on the immune cells (mast cells, dendritic cells, macrophage). (iii). Mediators: After that immune cells release different types of mediators (TNF, IL-1, IL-6). Mediators vary depending on the inducers type. (iv). Inflammation in Target Tissue: Immune mediators elicit their effects ( dilation of blood vessels, increased vascular permeability, movement of leukocytes from blood vessels to inured area etc.) on target tissues [3][4]. 
There are two forms of inflammation i.e., acute inflammation and chronic inflammation. Acute inflammation is pictured as immediate, short-term response and innate immunity to injury. Augmented movement of leukocytes from blood to the injured area results in acute inflammation within minutes or hours and lasted for short time to irradiate harmful stimuli. When the inflammatory responses last for long periods, it leads to chronic inflammation. Chronic inflammation leads to more complicated physiological condition and several diseases[5] i.e., neuroinflammation (brain), metabolic disorders ( liver/ pancreas) [6], osteoporosis ( bone) [7][8], cardiovascular disease (heart )[9], cancer [10], rheumatoid arthritis [11], obesity , asthma, Alzheimer's disease [12]etc.

\section{2. Role of Toll Like Receptor 4 (TLR4) Pathway in Inflammation}

In response to inflammatory inducers (signals i.e., bacterial lipopolysaccharides) pattern recognition receptors as well as transmembrane receptors play a pivotal role in initiation of immune response, among these, Toll like receptors are most significant [13]. TLR4 senses the harmful stimuli and recruits the coordinate activation of two distinct transcription factors i.e., Nuclear factor kappaß (NF-кB) and Interferon Regulatory Factor 3 (IRF3) (Figure 2) [14]-[16]. 


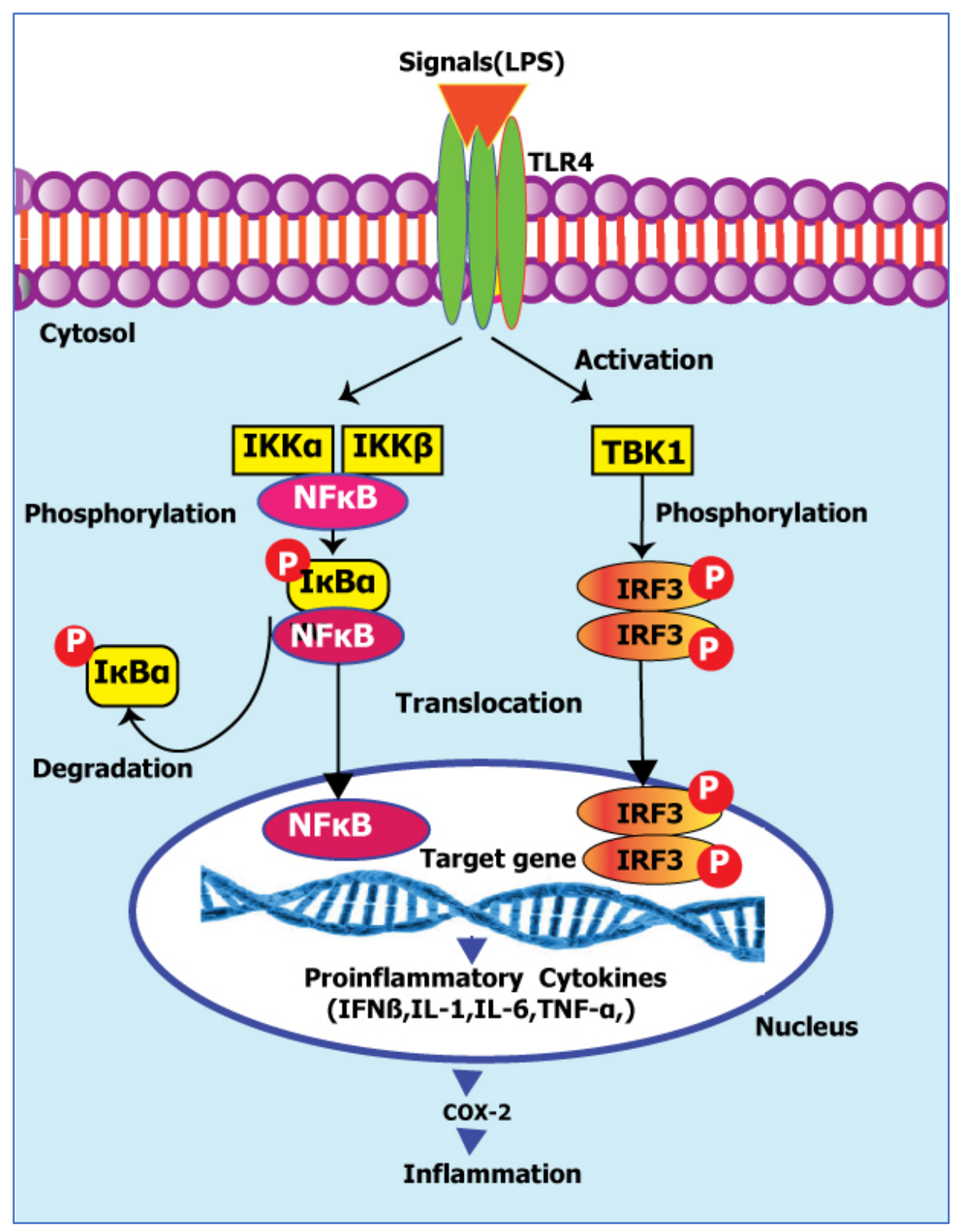

Figure 2: TLRs pathway. Sensing harmful stimuli, Toll like receptor4 (TLR4) gets activated and recruits the coordinate activation of two distinct transcription factors i.e., NF-кB and IRF3. Activated TLR4 at first activates both canonical (IKK $\alpha / \operatorname{IKK} \beta$ ) and noncanonical (TBK1) IkappaB kinases (IKB) and these kinases activate the NF-

$\kappa \mathrm{B}$ and IRF3 transcription factor respectively which leads to their translocation into nucleus and facilitates the transcription of proinflammatory genes.

In the resting cells, NF-кB is isolated by inhibitory proteins called, IkappaB/IкB kinase (IKK) in cytoplasm where these proteins act like a mask and inactivate NF-кB. In response to signals TLR4 is activated which in turn activate both canonical IкB kinases (ІкB kinase $\alpha / \beta$ IKK $\alpha, \mathrm{IKK} \beta$ ) and noncanonical IкB kinase, i.e., TBK1 (TANK binding kinase-1)[17]. Activated 
IKK $\alpha / \mathrm{IKK} \beta$ (IKK complex) phosphorylate $\mathrm{IKB} \alpha$ which is ubiquitinated and degraded and activate NF-кB. Activated TBK1 results in phosphorylation of IRF3 which in turn leads to formation of dimer complex. Both the activated NF-кB and IRF3 dimer translocate in the nucleus and facilitate the transcription of the gene of proinflammatory cytokines (TNF- $\alpha$, IL-1, IL-6, IFN- $\beta$ ). These proinflammatory cytokines cause fever, inflammation, pain, tissue destruction in human body. NF-кB plays a substantial role in the regulation and production of COX-2 which acts on arachidonic acid and facilitates it conversion into prostaglandins [18]-[20]. COX-2 expression is inducible and mainly expressed in immune cells and elicits pathophysiological functions. COX-2 produces high level PGs which play a substantial role in the inflammatory response where they act as inflammatory mediators. Dramatically augmented level of PGs develops cardinal signs of inflammation as well as pain, swelling and other physiological disorders [21].

\subsection{Current treatments of inflammation and limitation}

Nonsteroidal anti-inflammatory drugs (NSAIDs) are most commonly prescribed drugs for inflammation. These drugs reduce pain and immune response by inhibiting COX enzymes, TBK1 ( Amlexanox, FDA approved drug [22]) and IKK kinases ( Quilonoxaline) that take part in the synthesis of prostaglandins[23][24]. These drugs are classified into two groups i.e., Nonselective NSAIDs (aspirin, ibuprofen, naproxen etc.) and selective NSAIDs (celecoxib, rofecoxib). [25]-[29]. Treatment of inflammation with selective NSAIDs is lucrative. Because selective NSAIDs, selectively inhibits COX-2. As a result, body's homostatic functions are carried out perfectly. Recent studies show that, selective NSAIDs cause cardiovascular complications, disturbs normal renal function as COX-2 is involved in renal development 
[30][31] . As the use of these existing drugs is very challenging, plant-based medicines are more desirable as they found to have less side effects [32].

\subsection{Curcumin Analogues as Anti-inflammatory Agents}

Plants are sources of wide varieties of phytochemicals which provide range of therapeutic benefits in human body [33][34]. Curcumin is a dietary yellow pigment as well as potent antiinflammatory agent, found in turmeric (Curcuma longa) as it inhibits the prostaglandin (PG) synthesis which is crucial for the initiation of inflammation. There are various types of analogues of Curcumin, found in other plants of the mother nature [35]. Curcumin has been proven to have anti-inflammatory activities and down regulate the NF-кB activation and TLR4 pathway activity in inflammation in many pathways [36]-[38]. In a laboratory experiment Curcumin has been shown to inhibit COX-2 as well as COX-1 activity by $50 \%$ in a concentration of $15 \mu \mathrm{M}$ with slight selectivity [39]. In yet other studies Curcumin has been shown to inhibit IKK activity and downregulate NF-кB activation [40]. Curcumin Analogues Yakuchinone A and Yakuchinone B were also reported to inhibit COX-2 activity in laboratory experiment [41]. 6-Shogaol has similar structure as of Curcumin and a structural analogue of 6-Gingerol is an inhibitor of TBK-1[42]. In this experiment different Curcumin analogues have been analyzed to understand their inhibitory effects on multiple signaling proteins (targets) involved in inflammation based on the hypothesis that since they have similar structure and few analogues have target specific anti-inflammatory activity so one or more analogue(s) could have even better activity.

\begin{tabular}{|c|c|c|c|}
\hline Compound name & Source & PubChem CID & Reference \\
\hline Bisdemethoxycurcumin & $\begin{array}{c}\text { Turmeric } \\
(\text { Curcuma longa })\end{array}$ & 5315472 & {$[43]$} \\
\hline Curcumin & $\begin{array}{c}\text { Turmeric } \\
(\text { Curcuma longa })\end{array}$ & 969516 & {$[44]$} \\
\hline
\end{tabular}




\begin{tabular}{|c|c|c|c|}
\hline Cyclocurcumin & $\begin{array}{c}\text { Turmeric } \\
\text { (Curcuma longa })\end{array}$ & 69879809 & [45] \\
\hline Demethoxycurcumin & $\begin{array}{c}\text { Turmeric } \\
(\text { Curcuma longa })\end{array}$ & 5469424 & [43] \\
\hline
\end{tabular}

Table 1: Curcumin and it's natural derivatives from turmeric.

\begin{tabular}{|c|c|c|c|}
\hline $\begin{array}{l}\text { Compound } \\
\text { name }\end{array}$ & Source & PubChem CID & Reference \\
\hline 6-Gingerol & $\begin{array}{c}\text { Ginger } \\
\text { (Zingiber officinale Roscoe) }\end{array}$ & 442793 & {$[46]$} \\
\hline 6-Paradol & $\begin{array}{c}\text { Ginger } \\
\text { (Zingiber officinale Roscoe) }\end{array}$ & 94378 & {$[47][48]$} \\
\hline 6-Shogaol & $\begin{array}{c}\text { Ginger } \\
\text { (Zingiber officinale) }\end{array}$ & 5281794 & [49] \\
\hline Cassumunin A & $\begin{array}{c}\text { Ginger } \\
\text { (Zingiber cassumunar) }\end{array}$ & 10460395 & {$[50]$} \\
\hline Cassumunin B & $\begin{array}{c}\text { Ginger } \\
\text { (Zingiber cassumunar) }\end{array}$ & 10054109 & [50] \\
\hline Dehydrozingerone & $\begin{array}{c}\text { Ginger (Zingiber officinale } \\
\text { Roscoe) }\end{array}$ & 5354238 & [51] \\
\hline Dibenzoylmethane & $\begin{array}{c}\text { Licorice } \\
\text { (Glycyrrhiza echinata) }\end{array}$ & 8433 & [52] \\
\hline Isoeugenol & $\begin{array}{c}\text { Cloves } \\
\text { (Eugenia caryophyllus) }\end{array}$ & 853433 & [53] \\
\hline Yakuchinone A & $\begin{array}{c}\text { Galanga } \\
\text { (Alpinia officinarum) }\end{array}$ & 133145 & [54] \\
\hline Yakuchinone B & $\begin{array}{c}\text { Galanga } \\
\text { (Alpinia officinarum) }\end{array}$ & 6440365 & [54] \\
\hline
\end{tabular}

Table 2: Curcumin analogs from mother nature. 


\section{Literature Review}

14 Compounds

\section{Drug Likeness Filter}

12 Compounds

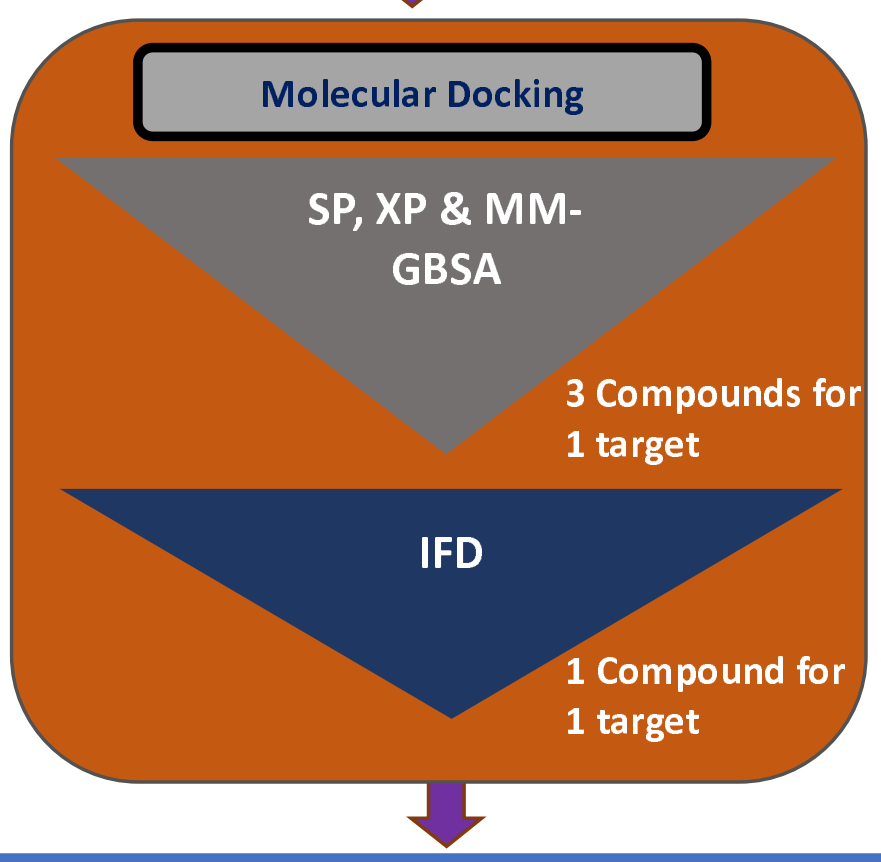

\section{Post Screening Study}

$\square$ ADME/T Prediction

$\square$ Pharmacological and Biological Activity Prediction

$\square$ P450 SOM Prediction

$\square$ DFT Calculation

Figure 3: Strategies employed in the overall study. 


\section{Materials and Methods}

A total of 14 compounds comprising Curcumin, its derivatives and analogs were selected from literature review. Then they were subjected to drug likeness property analysis, molecular docking, and other experiments to identify best inhibitors of the respective targets (Figure 3).

\subsection{Drug Likeness Property Analysis}

The selected ligand molecules were analyzed to determine whether they obey Lipinski's rule of five or not which states that a drug is considered to have poor bioavailability and low permeation which violates the standard rule [55][56]. Canonical smile of each intended ligand molecule was retrieved from PubChem database (https://pubchem.ncbi.nlm.nih.gov/) and was then analyzed using the Molonspiration Cheminformatics server (https://www.molinspiration.com/cgibin/properties) for different drug-likeness parameters (Table 3)[57][58]. Compounds violating the rule were then opted out from consideration and further evaluation.

\subsection{Molecular Docking Experiment}

\subsubsection{Protein Preparation}

Three dimensional crystallized structure of Human COX-2 (PDB ID:5F1A), Inhibitor of kappaB kinase beta (PDB ID: 3RZF) and Tank Binding Kinase-1 (PDB ID:5W5V) were downloaded in PDB format from Protein Data Bank (www.rcsb.org) [59]-[61]. The structures were then prepared and processed using the Protein Preparation Wizard in Maestro Schrödinger Suite (v11.4). Bond orders were assigned to the structures, hydrogens were added to heavy atoms. All of the water molecules were erased from the atoms, missing side chains were added to the protein backbone using Prime and het states were generated with Epik at $\mathrm{pH} 7 \pm 2$ [62]. At last, the structures were refined and then minimized utilizing Optimized Potentials for Liquid 
Simulations force field (OPLS_2005). Minimization was performed setting the greatest substantial particle RMSD (root-mean-square-deviation) to $30 \AA$ and any extraordinary water under $3 \mathrm{H}$-bonds to non-water was again eradicated during the minimization step.

\subsubsection{Ligand Preparation}

A total of 12 ligand molecules except those that violated Lipinski's rule of five were downloaded in sdf format from PubChem database (https://pubchem.ncbi.nlm.nih.gov/) [63]. These structures were then processed and prepared using the LigPrep wizard of Maestro Schrödinger suite [64]. Minimized 3D structures of ligands were generated using Epik2.2 and within $\mathrm{pH} 7.0+/-2.0$ in the suite. Minimization was again carried out using OPLS_2005 force field which generated maximum 32 possible stereoisomers depending on available chiral centers on each molecule.

\subsubsection{Receptor Grid Generation}

Grid usually confines the active site to specific area of the receptor protein for the ligand to dock specifically within selected area. Receptor grid was generated using default Van der Waals radius scaling factor 1.0 and charge cutoff 0.25 which was then subjected to OPLS_2005 force field for the minimized structure in Glide [65]. A cubic box was then generated around the active site (co-crystallized reference ligand) of the target molecules. The grid box dimension was then adjusted to $14 \AA \times 14 \AA \times 14 \AA$ for docking to be carried out.

\subsubsection{Glide Standard Precision (SP) and Extra Precision Ligand Docking}

Extra precision (XP) ligand docking is more accurate for small number of ligand molecules than standard precision (SP) ligand docking which is recommended for large compound libraries [66]. But both of the docking methods were applied for the selected ligand molecules and intended targets for making comparison. The Van der Waals radius scaling factor and charge cutoff were set to 0.80 and 0.15 respectively for all the ligand molecules under study. Final score was 
assigned according to the pose of docked ligand within the binding cleft of the receptor molecules. Best possible poses and types of ligand-receptor interactions were then analyzed utilizing Discovery Studio Visualizer (v4.5) (Figure 4) [67].

\subsubsection{Prime MM-GBSA Rescoring}

After SP and XP ligand docking the ligands were then again subjected to Molecular mechanics generalized born and surface area (MM-GBSA) rescoring with the help of Prime module of Maestro Schrödinger suite for further evaluation. This technique utilizes an implicit solvent which then assigns more accurate scoring function that then improves the overall free binding affinity score upon the reprocessing of the docked complex [66][68]. It combines OPLS molecular mechanics energies $\left(\mathrm{E}_{\mathrm{MM}}\right)$, surface generalized born solvation model for polar solvation $\left(\mathrm{G}_{\mathrm{SGB}}\right)$, and a nonpolar salvation term $\left(\mathrm{G}_{\mathrm{NP}}\right)$ for total free energy $\left(\Delta \mathrm{G}_{\mathrm{bind}}\right)$ calculation. The total free energy of binding was calculated by the following equation:

$\Delta \mathbf{G}_{\text {bind }}=\mathbf{G}_{\text {complex }}-\left(\mathbf{G}_{\text {protein }}-\mathbf{G}_{\text {ligand }}\right)$, where, $\mathbf{G}=\mathbf{E}_{\mathrm{MM}}+\mathbf{G}_{\mathrm{SGB}}+\mathbf{G}_{\mathrm{NP}}$

The result of SP docking, XP docking and MM-GBSA rescoring is summarized in Table 4.

\subsubsection{Induced Fit Docking}

Three compounds were selected based on the lowest MM-GBSA score for each of the receptor molecule which were then used for further evaluation since it is more robust scoring method. At this stage, different scores of three best docked compounds were compared with one approved known inhibitor (control) i.e., Celecoxib, Salfasalazine and Fostamatinib for COX-2, IKK and TBK-1 (Table 5) receptor respectively [69]. After that the best three ligands for each receptor were subjected to induced fit docking (IFD) which is even more accurate docking method to generate the native poses of the ligands [70]. Again OPLS_2005 force field was applied after generating grid around the co-crystallized ligand of the receptor and this time the best five 
ligands were docked rigidly. Receptor and Ligand Van Der Waals screening was set at 0.70 and 0.50 respectively, residues within $2 \AA$ were refined to generate 2 best possible posses with extra precision. Best performing ligand was selected according to the IFD score for one receptor molecule (Table 6). Then all three selected ligands for three receptors were used in the next phases of this study.

\subsection{Ligand-based ADME/T Prediction}

In silico prediction of ADME/T profile of candidate drug molecule helps to increase the success rate of drug discovery expenditure [71][72]. Canonical smiles of the best three ligand were used to predict drug like potential and tentative pharmacokinetic and pharmacodynamic parameters. ADME/T profile of each ligand was predicted using admetSAR 2.0 (http://lmmd.ecust.edu.cn/admetsar2/) and pkCSM server (http://biosig.unimelb.edu.au/pkcsm/) [73][74] (Table 7).

\subsection{Pharmacological and Biological Activity Prediction}

Pharmacological and biological activities of the best ligand molecules were predicted using PASS (Prediction of Activity Spectra of Substances) Online (http://www.pharmaexpert.ru/passonline/) and Molinspiration Cheminformatics servers respectively (Table $8 \& \mathbf{~ 9 )}$ [58][75]. These tools predict the tentative activities of compounds based on structure activity relationship (SAR) in correlation with a known compound existing in the database.

\subsection{P450 Site of Metabolism Prediction}

In silico analysis of potential sites of metabolism of candidate drug metabolism provides insights into the metabolic vulnerability of the molecule inside in human body which then drives the in vitro assay [76]. Best metabolism sites of best three ligands to three isoforms i.e. CYP3A4, 
CYP2D6 and CYP2C9 of Cytochrome P450 family of enzymes were predicted utilizing onlinebased RS-WebPredictor server (http://reccr.chem.rpi.edu/Software/RS-WebPredictor/) (Figure 5) $[77]$.

\subsection{DFT (Density Functional Theory) Calculation}

Minimized ligand structures was obtained from LigPrep which were then used for DFT calculation using the Jaguar panel of Maestro Schrödinger Suite using Becke's three-parameter exchange potential and Lee-Yang-Parr correlation functional (B3LYP) theory with 6-31G* basis set in the suite [78]-[81]. Quantum chemical properties i.e. surface properties (MO, density, potential) and Multipole moments were calculated along with HOMO (Highest Occupied Molecular Orbital) and LUMO (Lowest Unoccupied Molecular Orbital) energy. Global frontier orbital was analyzed along with hardness $(\boldsymbol{\eta})$ and softness $(\mathbf{S})$ of selected molecules were also calculated using the following equation as per Parr and Pearson interpretation and Koopmans theorem [82][83]. The result of DFT calculation is summarized in Table 10. HOMO and LUMO occupation of the ligands is illustrated in Figure 6.

$\eta=(H O M O \square-L U M O \square) / 2, S=1 / \eta$

\section{Results}

\subsection{Drug Likeness Property}

14 selected ligand molecules were analyzed to understand whether they comply Lipinski's rule of five or not. Cassumunin A and Cassumunin B violated the standard rule and hence were removed for further consideration (Table 3). All other ligand molecules were reported to obey Lipinski's rule of five. These 12 ligand molecules were then utilized in the next phases of the experiment. 


\begin{tabular}{|c|c|c|c|c|c|c|c|c|}
\hline $\begin{array}{c}\text { SL. } \\
\text { No. }\end{array}$ & Compound Name & $\begin{array}{c}\text { MW } \\
(\mathrm{g} / \mathrm{mol})\end{array}$ & miLogP & HBA & HBD & nROTB & $\begin{array}{c}\text { TPSA } \\
\left(\AA^{2}\right)\end{array}$ & $\begin{array}{c}\text { Lipinski } \\
\text { Violation }\end{array}$ \\
\hline Rule & & $<500$ & $\leq 5$ & $<10$ & $<5$ & $\leq 10$ & & \\
\hline 01. & 6-Gingerol & 294.39 & 3.22 & 4 & 2 & 10 & 66.76 & 0 \\
\hline 02. & 6-Paradol & 278.39 & 4.60 & 3 & 1 & 10 & 46.53 & 0 \\
\hline & 6-Shogaol & 276.38 & 4.35 & 3 & 1 & 9 & 46.53 & 0 \\
\hline 03. & Bisdemethoxycurcumin & 308.33 & 2.67 & 4 & 2 & 6 & 74.60 & 0 \\
\hline 04. & Cassumunin A & 558.63 & 4.96 & 8 & 2 & 13 & 111.53 & 1 \\
\hline 05. & Cassumunin B & 588.65 & 4.77 & 9 & 2 & 14 & 120.77 & 1 \\
\hline 06. & Curcumin & 368.38 & 2.30 & 6 & 2 & 8 & 93.07 & 0 \\
\hline 07. & Cyclocurcumin & 368.38 & 3.03 & 6 & 2 & 5 & 85.23 & 0 \\
\hline 08. & Dehydrozingerone & 192.21 & 1.55 & 3 & 1 & 3 & 46.53 & 0 \\
\hline 09. & Demethoxycurcumin & 338.36 & 2.48 & 5 & 2 & 7 & 83.83 & 0 \\
\hline 10. & Dibenzoylmethane & 224.26 & 2.88 & 2 & 0 & 4 & 34.14 & 0 \\
\hline 11. & Isoeugenol & 164.20 & 2.38 & 2 & 1 & 2 & 29.46 & 0 \\
\hline 12. & Yakuchinone A & 312.41 & 4.24 & 3 & 1 & 9 & 46.53 & 0 \\
\hline 13. & Yakuchinone B & 310.39 & 4.27 & 3 & 1 & 8 & 46.53 & 0 \\
\hline
\end{tabular}

Table 3: Results of drug likeness property analysis. HBA; Hydrogen bond acceptors; HBD: Hydrogen bond donors, nROTB: Number of rotatable bonds; TPSA: Topological Polar Surface Area.

Alongside the standard rule, the ligands were also analyzed for their Topological Polar Surface Area (TPSA), Isoeugenol was reported to have lowest TPSA and Curcumin was reported to have highest TPSA. Other ligands have TPSA within the moderate range among the highest and lowest values.

\subsection{Molecular Docking Experiment}

12 selected ligand molecules from the drug likeness property analysis were then utilized in the docking experiment against COX-2, IKK and TBK-1. Both standard precision (SP) and extra precision (XP) ligand docking were carried out. A slight variation between SP and XP ligand 
docking was observed. Then the docked complexes were utilized to calculate binding free energies and three best compounds with lowest binding energy were selected for each target molecule (Table 4). At this stage the docking parameters of approved known inhibitors (controls) of respective receptors were compared with that of the ligand of our specific interest.

Cyclocurcumin, 6-Gingerol and Demethoxycurcumin docked with COX-2 with -46.310 $\mathrm{Kcal} / \mathrm{mol},-57.913 \mathrm{Kcal} / \mathrm{mol}$ and $-55.740 \mathrm{Kcal} / \mathrm{mol}$ free binding energies. And all of these ligand molecules showed lowest binding free energies than Celecoxib $(-39.873 \mathrm{Kcal} / \mathrm{mol})$ (control) (Table 4).

\begin{tabular}{|c|c|c|c|c|c|c|}
\hline $\begin{array}{l}\text { Receptor } \\
\text { Name }\end{array}$ & Compound Name & $\begin{array}{c}\text { SP } \\
\text { Docking } \\
\text { Score } \\
(\mathrm{Kcal} / \mathrm{mol})\end{array}$ & $\begin{array}{c}\text { XP } \\
\text { Docking } \\
\text { Score } \\
\text { (Kcal } / \mathrm{mol})\end{array}$ & $\begin{array}{c}\text { Glide } \\
\text { Energy }\end{array}$ & $\begin{array}{c}\text { Glide- } \\
\text { ligand } \\
\text { Efficiency }\end{array}$ & $\begin{array}{c}\text { MM- } \\
\text { GBSA } \\
\Delta \mathrm{G}_{\mathrm{bind}} \\
(\mathrm{Kcal} / \mathrm{mol})\end{array}$ \\
\hline \multirow[t]{4}{*}{$\mathrm{COX}-2$} & $\begin{array}{c}\text { Celecoxib } \\
\text { (control) }\end{array}$ & -4.854 & -6.139 & -29.387 & -0.186 & -39.873 \\
\hline & Cyclocurcumin & -7.394 & -7.962 & -49.949 & -0.336 & -46.310 \\
\hline & 6-Gingerol & -5.368 & -6.693 & -52.051 & -0.271 & -57.913 \\
\hline & Demethoxycurcumin & -5.909 & -6.622 & -50.027 & -0.225 & -55.740 \\
\hline \multirow[t]{4}{*}{ IKK } & $\begin{array}{c}\text { Salfasalazine } \\
\text { (control) }\end{array}$ & -4.949 & -5.131 & -43.935 & -0.183 & -55.510 \\
\hline & Yakuchinone A & -6.283 & -7.791 & -38.429 & -0.339 & -69.953 \\
\hline & Yakuchinone B & -6.918 & -6.895 & -36.961 & -0.300 & -68.737 \\
\hline & 6-Paradol & -4.494 & -5.555 & -34.138 & -0.278 & -68.553 \\
\hline \multirow[t]{4}{*}{ TBK-1 } & $\begin{array}{c}\text { Fostamatinib } \\
\text { (control) }\end{array}$ & -6.980 & -5.518 & -63.716 & -0.138 & -53.750 \\
\hline & Yakuchinone B & -7.066 & -7.837 & -38.540 & -0.341 & -56.043 \\
\hline & Yakuchinone A & -7.189 & -7.393 & -38.764 & -0.321 & -52.469 \\
\hline & Curcumin & -6.273 & -6.266 & -43.968 & -0.232 & -52.819 \\
\hline
\end{tabular}

Table 4: Results of SP, XP docking and Free binding energy calculation between intended target and ligand molecules.

Yakuchinone A, Yakuchinone B and 6-Paradol docked with IKK with -69.953 Kcal/mol, -68.737 $\mathrm{Kcal} / \mathrm{mol}$ and $-68.553 \mathrm{Kcal} / \mathrm{mol}$ respectively. Control of this experiment (Salfasalazine) 
generated notably more positive free binding energy score $(-55.510 \mathrm{Kcal} / \mathrm{mol})$ than all compounds under investigation.

Again, Yakuchinone A, Yakuchinone B and Curcumin docked with TBK-1 with -52.469 $\mathrm{Kcal} / \mathrm{mol},-56.043 \mathrm{Kcal} / \mathrm{mol}$ and $-52.819 \mathrm{Kcal} / \mathrm{mol}$ free binding energies whereas Fostamatinib (control) showed slightly positive score $-53.750 \mathrm{Kcal} / \mathrm{mol}$. These three ligand molecules for each receptor were then subjected to induced fit docking (IFD) which is more powerful tool to predict the ligand-receptor interaction with better accuracy in pose prediction. One best ligand was selected for each ligand based on IFD score and those ligands were then analyzed for their drug potential.

\subsubsection{Binding Mode of 6-Gingerol with $\mathrm{COX}-2$}

6-Gingerol docked with COX-2 with an IFD score of -2474.460 Kcal/mol and XP Gscore of -

$9.264 \mathrm{Kcal} / \mathrm{mol}$ (Table 5). It formed 5 conventional hydrogen bonds with Gln454, His214, Tyr385, Thr212 and Asn382 amino acid residues inside the binding pocket of COX-2 at $2.01 \AA$, $2.29 \AA, 1.93 \AA, 3.60 \AA$ and $2.52 \AA$ respectively. It also formed 1 non-conventional hydrogen bond with His388 amino acids and few other hydrophobic interactions i.e., Pi-Pi Stacked, Pi-Pi T Shaped and Pi-Alkyl interactions with interacting amino acids inside the binding cleft of COX-2. It interacted with 11 amino acids in total inside the binding site of COX-2 (Figure 4). 


\begin{tabular}{|c|c|c|c|c|c|c|c|}
\hline $\begin{array}{l}\text { Target } \\
\text { Name }\end{array}$ & Ligand Name & $\begin{array}{c}\text { IFD } \\
\text { Score } \\
(\text { Kcal/mol) }\end{array}$ & $\begin{array}{c}\text { XP } \\
\text { Gscore } \\
\text { (Kcal/mol) }\end{array}$ & $\begin{array}{c}\text { Interacting } \\
\text { Amino } \\
\text { Acids }\end{array}$ & $\begin{array}{c}\text { Bond } \\
\text { Distance } \\
(\AA)\end{array}$ & $\begin{array}{c}\text { Type of } \\
\text { Interaction }\end{array}$ & $\begin{array}{c}\text { Interaction } \\
\text { Category }\end{array}$ \\
\hline \multirow{11}{*}{$\mathrm{COX}-2$} & \multirow{11}{*}{ 6-Gingerol } & \multirow{11}{*}{-2474.460} & \multirow{11}{*}{-9.264} & Gln454 & 2.01 & Hydrogen bond & Conventional \\
\hline & & & & His386 & 4.74 & Pi-Pi Stacked & Hydrophobic \\
\hline & & & & HIS207 & 4.48 & Pi-Pi T Shaped & Hydrophobic \\
\hline & & & & His214 & 2.29 & Hydrogen bond & Conventional \\
\hline & & & & Tyr385 & 1.93 & Hydrogen bond & Conventional \\
\hline & & & & Thr212 & 3.60 & Hydrogen bond & Conventional \\
\hline & & & & His388 & 2.03 & Hydrogen bond & $\begin{array}{c}\text { Non- } \\
\text { conventional }\end{array}$ \\
\hline & & & & Asn382 & 2.52 & Hydrogen bond & Conventional \\
\hline & & & & Met458 & 4.84 & Pi-Alkyl & Hydrophobic \\
\hline & & & & Tyr148 & 4.15 & Pi-Alkyl & Hydrophobic \\
\hline & & & & Ala379 & 3.71 & Pi-Alkyl & Hydrophobic \\
\hline \multirow{9}{*}{ IKK } & \multirow{9}{*}{ Yakuchinone A } & \multirow{9}{*}{-1081.370} & \multirow{9}{*}{-9.111} & Lys 106 & 5.46 & Hydrogen bond & Conventional \\
\hline & & & & Met96 & 4.26 & Pi-Alkyl & Hydrophobic \\
\hline & & & & Lys 106 & 2.00 & Hydrogen bond & Conventional \\
\hline & & & & Ala42 & 4.27 & Pi-Alkyl & Hydrophobic \\
\hline & & & & Glu100 & 2.72 & Hydrogen bond & Conventional \\
\hline & & & & Ile165 & 5.19 & Pi-Alkyl & Hydrophobic \\
\hline & & & & Glu100 & 3.04 & Hydrogen bond & $\begin{array}{c}\text { Non- } \\
\text { conventional }\end{array}$ \\
\hline & & & & Val29 & 3.93 & Pi-Alkyl & Hydrophobic \\
\hline & & & & Cys99 & 1.96 & Hydrogen bond & Conventional \\
\hline \multirow{9}{*}{ TBK-1 } & \multirow{9}{*}{ Yakuchinone B } & \multirow{9}{*}{-1309.340} & \multirow{9}{*}{-7.971} & Val23 & 2.71 & Pi-Sigma & Hydrophobic \\
\hline & & & & Met142 & 5.21 & Pi-Alkyl & Hydrophobic \\
\hline & & & & Gly139 & 2.60 & Hydrogen bond & $\begin{array}{c}\text { Non- } \\
\text { conventional }\end{array}$ \\
\hline & & & & Ser93 & 2.84 & Hydrogen bond & Conventional \\
\hline & & & & Leu 15 & 5.17 & Pi-Alkyl & Hydrophobic \\
\hline & & & & Gly92 & 4.68 & Amide-Pi Stacked & \\
\hline & & & & Cys89 & 2.09 & Hydrogen bond & Conventional \\
\hline & & & & Phe88 & 2.76 & Hydrogen bond & $\begin{array}{c}\text { Non- } \\
\text { conventional }\end{array}$ \\
\hline & & & & Gly139 & 2.81 & Hydrogen bond & $\begin{array}{c}\text { Non- } \\
\text { conventional }\end{array}$ \\
\hline
\end{tabular}

Table 5: Result of induced fit docking (IFD) between best performing ligand and respective target. 
Yakuchinone A docked with IKK with an IFD score of $-1081.370 \mathrm{Kcal} / \mathrm{mol}$ and XP Gscore of -

9.111 Kcal/mol (Table 5). It formed 2 conventional hydrogen bonds with Lys106 amino acid residue inside the binding pocket of IKK at $5.46 \AA$ and $2.00 \AA$ distance apart respectively. Again, it formed 2 additional conventional hydrogen bonds with Glu100 and Cys99 amino acids at 2.72 $\AA$ and $1.96 \AA$ distance apart respectively. Yakuchinone A formed 1 nonconventional hydrogen bond with Glu100 amino acid residue and few other Pi-Alkyl interactions with interacting amino acids inside the binding cleft of IKK. It interacted with 7 amino acids in total inside the binding site of IKK (Figure 4).

\subsubsection{Binding Mode of Yakuchinone B with TBK-1}

Yakuchinone B docked with TBK-1 with an IFD score of $-1309.340 \mathrm{Kcal} / \mathrm{mol}$ and XP Gscore of -7.971 Kcal/mol (Table 5). It formed 2 conventional hydrogen bonds with Ser93 and Cys89 amino acid residues inside the binding pocket of TBK-1 at $5.46 \AA$ and $2.00 \AA$ distance apart respectively. Again, it formed 3 additional non-conventional hydrogen bonds with Gly139 and Phe88 amino acids. Yakuchinone B formed few other hydrophobic interactions i.e., Pi-Sigma, Pi-Alkyl and Amide-Pi Stacked with interacting amino acids inside the binding cleft of TBK-1. It interacted with 7 amino acids in total inside the binding site of TBK-1 (Figure 4) 
COX-2 and 6gingerol

IKK and Yakuchinone A

TBK-1 and Yakuchinone B
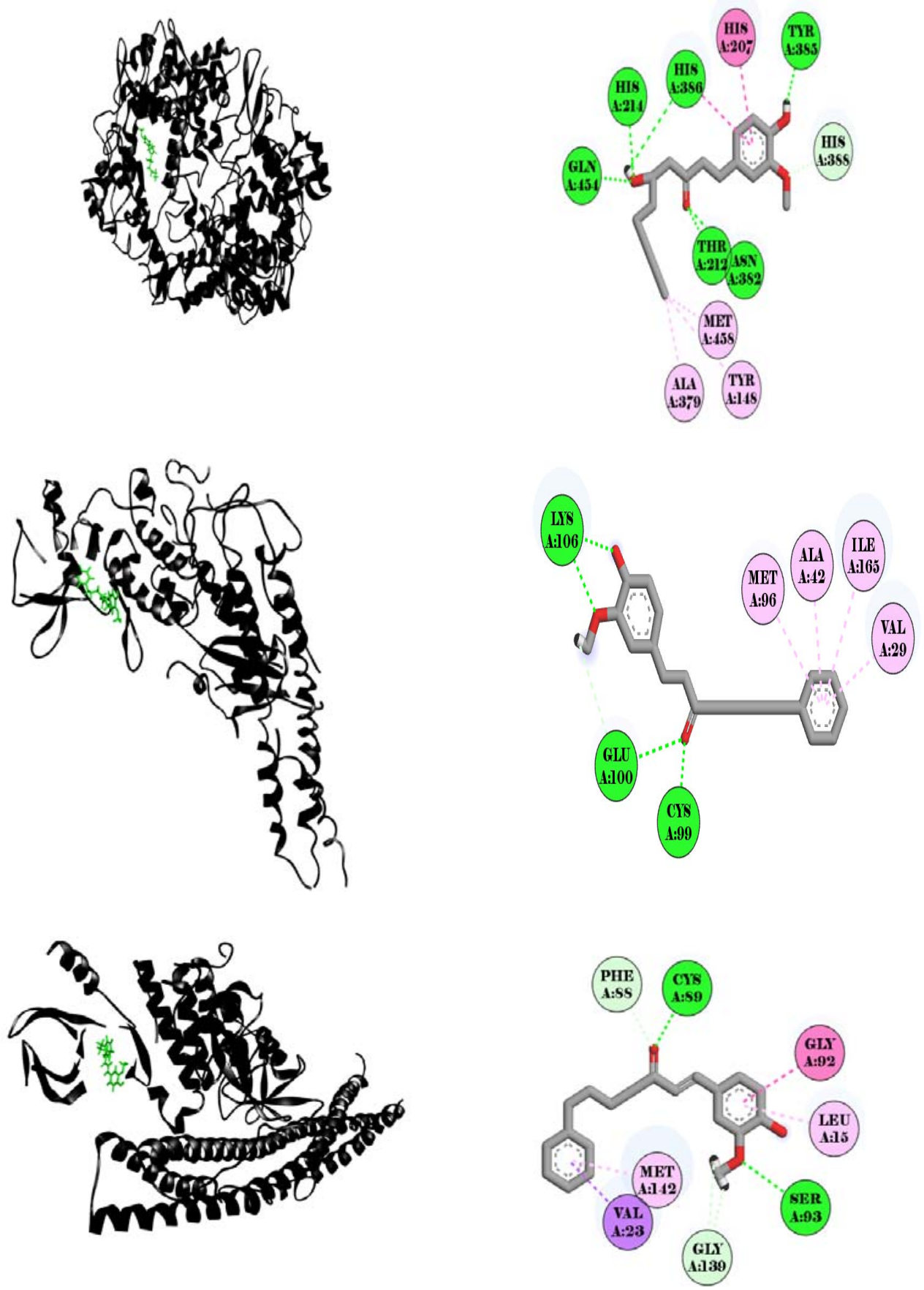

Figure 4: (A) Three dimensional representation of best possible poses of ligand molecules (green, stick) inside the binding pocket of intended target (black, ribbon). (B) Two dimensional representation of ligand-receptor interaction. Interacting amino acids are represented in three letter code and their respective number in specific chain inside disc. Dotted lines represent type of interactions: Green: Conventional hydrogen bond; Light green: Pi-Donor and Carbon hydrogen Bond. Pink: Amide-Pi stacked, Pi-Pi stacked and Pi-Pi T shaped; Light pink: Alkyl and Pi-Alkyl. 


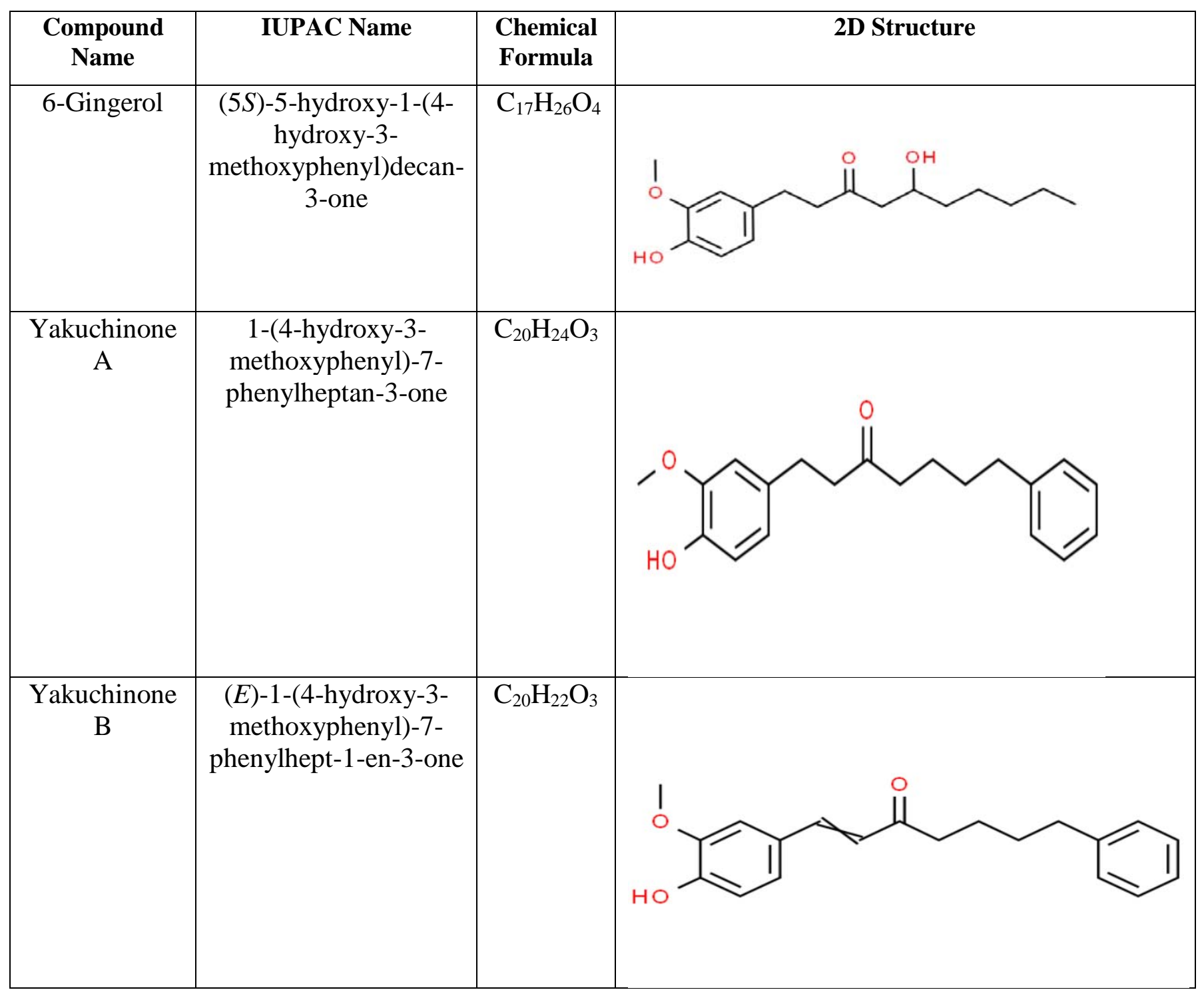

Table 6: Best performed ligand in overall docking experiment.

\subsection{ADME/T Prediction}

Best three selected ligand molecules (Table 6) were analyzed for their potential ADME/T profiles (Table 7). All of the ligand molecules were predicted to have high intestinal absorption and low oral bioavailability. Only Yakuchinone B has lower Caco-2 permeability. All of them are non-substrates of membrane P-glycoproteins and capable of penetrating blood brain barrier. 
Only 6-Gingerol was reported to be inhibitor of P-glycoproteins. All of them were reported to be the substrate of CYP3A4 and 6-Gingerol and Yakuchinone A are substrates of CYP2D6. None of them showed sign of inhibition towards CYP3A4, CYP2D6 and CYP2C9.

\begin{tabular}{|c|c|c|c|}
\hline Properties & 6-Gingerol & Yakuchinone A & Yakuchinone B \\
\hline \multicolumn{4}{|c|}{ Absorption } \\
\hline $\begin{array}{l}\text { Human intestinal } \\
\text { absorption }\end{array}$ & High & High & High \\
\hline $\begin{array}{c}\text { Human oral } \\
\text { bioavailability }\end{array}$ & Low & Low & Low \\
\hline Caco-2 permeability & High & High & Low \\
\hline \multicolumn{4}{|c|}{ Distribution } \\
\hline P-glycoprotein substrate & No & No & No \\
\hline P-glycoprotein inhibitor & Yes & No & No \\
\hline $\begin{array}{c}\text { Blood-brain barrier } \\
\text { penetration }\end{array}$ & Yes & Yes & Yes \\
\hline \multicolumn{4}{|c|}{ Metabolism } \\
\hline CYP3A4 substrate & Yes & Yes & Yes \\
\hline CYP2C9 substrate & No & No & No \\
\hline CYP2D6 substrate & Yes & Yes & No \\
\hline CYP3A4 inhibition & No & No & No \\
\hline CYP2C9 inhibition & No & No & No \\
\hline CYP2D6 inhibition & No & No & No \\
\hline \multicolumn{4}{|c|}{ Excretion } \\
\hline Total clearance & 1.339 & 0.346 & 0.231 \\
\hline OCT2 substrate & No & No & No \\
\hline \multicolumn{4}{|c|}{ Toxicity } \\
\hline AMES toxicity & No & No & No \\
\hline Hepatotoxicity & No & No & No \\
\hline$h E R G$ inhibition & Yes & Yes & Yes \\
\hline Eye irritation & Yes & No & No \\
\hline Acute oral toxicity & Type III & Type III & Type III \\
\hline
\end{tabular}

Table 7: Results of ADME/T tests of best selected ligands. OCT2: Organic Cation Transporter 2; $h E R G$ : Human ether-a-go-go related gene, CYP: Cytochrome P450

None of the ligands was reported to be OCT2 (Organic Cation Transporter 2) substrate and show AMES toxicity and Hepatotoxicity. All of the ligands were reported to be inhibitors of $h E R G$ (Human ether-a-go-go related gene) channel. Only 6-Gingerol showed sign of eye irritation. All ligands showed Type III acute oral toxicity.

\subsection{Pharmacological and Biological Activity Prediction}


Best three ligand molecules were analyzed for their tentative pharmacological activities (Table 8). They were analyzed to understand their association with anti-inflammatory and other activities with enzymes, signaling proteins, transcription factors and cytokines involved in inflammatory cascades (Table 8).

\begin{tabular}{|c|c|c|c|c|c|c|}
\hline \multirow{2}{*}{$\begin{array}{c}\text { Pharmacological } \\
\text { Activity }\end{array}$} & \multicolumn{2}{|c|}{ 6-Gingerol } & \multicolumn{2}{c|}{ Yakuchinone A } & \multicolumn{2}{c|}{ Yakuchinone B } \\
\cline { 2 - 7 } & $\mathbf{P a}$ & $\mathbf{P i}$ & $\mathbf{P a}$ & $\mathbf{P i}$ & $\mathbf{P a}$ & $\mathbf{P i}$ \\
\hline Antiinflammatory & 0.532 & 0.532 & 0.497 & 0.058 & 0.576 & 0.037 \\
\hline $\begin{array}{c}\text { Antiinflammatory, } \\
\text { intestinal }\end{array}$ & 0.566 & 0.004 & 0.437 & 0.015 & 0.519 & 0.006 \\
\hline $\begin{array}{c}\text { Antiinflammatory, } \\
\text { ophthalmic }\end{array}$ & 0.343 & 0.343 & 0.330 & 0.043 & 0.329 & 0.044 \\
\hline MAP kinase stimulant & 0.482 & 0.049 & 0.667 & 0.008 & 0.658 & 0.009 \\
\hline $\begin{array}{c}\text { TNF expression } \\
\text { inhibitor }\end{array}$ & 0.633 & 0.010 & 0.595 & 0.014 & 0.804 & 0.004 \\
\hline $\begin{array}{c}\text { JAK2 expression } \\
\text { inhibitor }\end{array}$ & 0.679 & 0.020 & 0.863 & 0.004 & 0.945 & 0.002 \\
\hline NF kappa A inhibitor & 0.228 & 0.115 & 0.278 & 0.048 & 0.266 & 0.059 \\
\hline NF kappa B inhibitor & 0.264 & 0.015 & 0.240 & 0.018 & 0.341 & 0.009 \\
\hline $\begin{array}{c}\text { Macrophage colony } \\
\text { stimulating factor } \\
\text { agonist }\end{array}$ & 0.762 & 0.007 & 0.687 & 0.015 & 0.569 & 0.040 \\
\hline $\begin{array}{c}\text { Cyclooxygenase } \\
\text { substrate }\end{array}$ & 0.326 & 0.011 & 0.230 & 0.058 & 0.224 & 0.064 \\
\hline
\end{tabular}

Table 8: Result of Pharmacological Activity prediction of selected ligand molecules. Pa>0.7: Compound is very likely to have activity; $\mathrm{Pa}>0.5$ : Compound is likely to have activity; $\mathrm{Pa}>0.3$ : Compound is less likely to have activity.

Probability scores of intended pharmacological activities of investigated ligands varied with variety of extent and Yakuchinone B performed slightly better in the pharmacological activity prediction experiment followed by Yakuchinone B and 6-Gingerol. Yakuchinone B showed activities as TNF expression inhibitor and JAK2 expression inhibitor with probability score greater than 0.7. 6-Gingerol showed Macrophage colony stimulating factor agonist activity with 
probability score greater than 0.7 . Other scores of intended activities by selected ligand molecules ranged from moderate to low.

Thereafter, the selected ligands were investigated for their biological activities against GPCR ligand, ion channels, enzyme etc. (Table 9). 6-gingerol showed better positive scores as Enzyme inhibitor, Nuclear receptor ligand and GPCR ligand modulator with higher positive probability scores. However, Yakuchinone A and Yakuchinone B also showed similar activities against few parameters.

\begin{tabular}{|c|c|c|c|}
\hline \multirow{2}{*}{ Bioactivity } & \multicolumn{3}{|c|}{ Score } \\
\cline { 2 - 4 } & 6- Gingerol & Yakuchinone A & Yakuchinone B \\
\hline GPCR ligand & 0.16 & 0.07 & -0.00 \\
\hline Ion channel modulator & 0.04 & -0.02 & -0.17 \\
\hline Kinase inhibitor & -0.33 & -0.31 & -0.36 \\
\hline Nuclear receptor ligand & 0.20 & 0.12 & 0.17 \\
\hline Protease inhibitor & 0.15 & 0.01 & -0.09 \\
\hline Enzyme inhibitor & 0.38 & 0.16 & 0.13 \\
\hline
\end{tabular}

Table 9: Result of biological activity prediction of best ligands.

\subsection{P450 Site of Metabolism Prediction}

Best selected ligand molecules were examined for their potential sites of metabolism against three major isoforms of Cytochrome P450 family of enzymes i.e., CYP3A4; CYP2D6 and CYP2C9 (Figure 5). All of the selected ligand molecules were reported to have multiple atoms which are vulnerable to a specific enzyme of CYP450 family. 6-Gingerol showed almost similar sites of metabolism for all three isoforms but Yaluchinone A and Yakuchinone B showed different potential metabolism sites for metabolism by different emzymes. 
Enzyme

\section{CYP3A4}

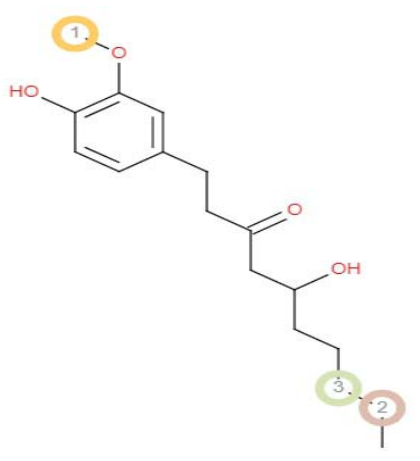

CYP2D6

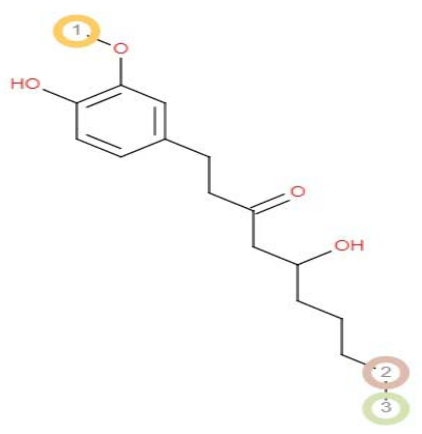

CYP2C9

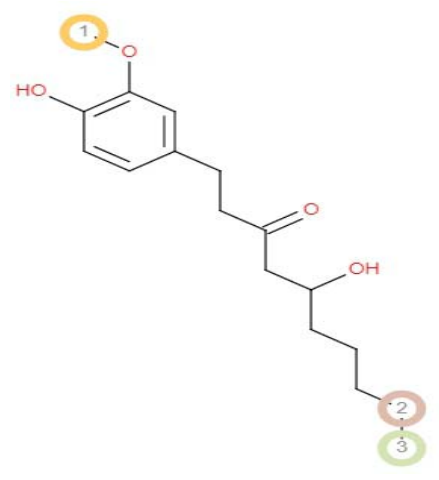

Yakuchinone A
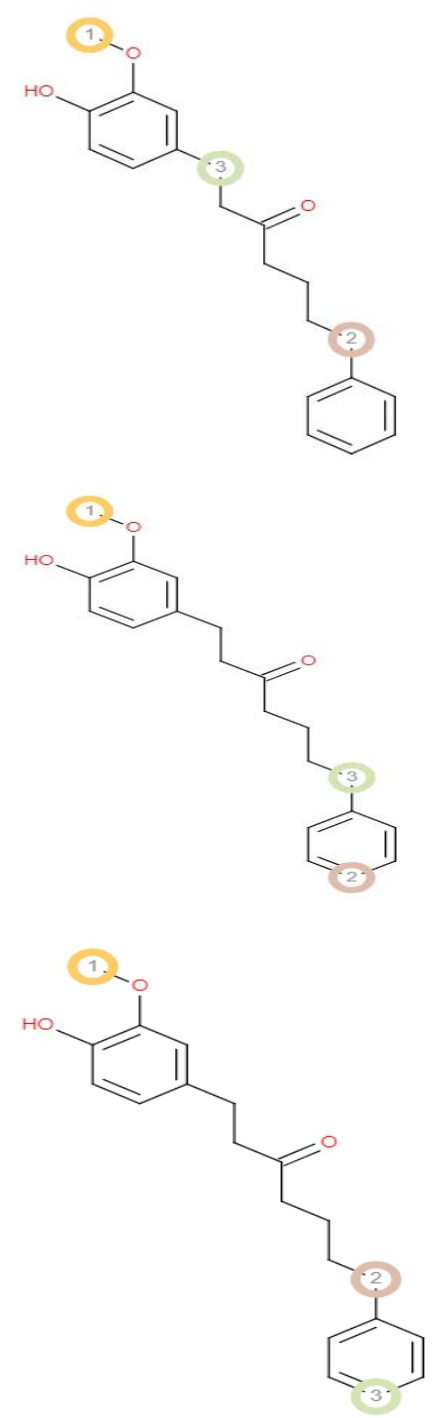

Yakuchinone B
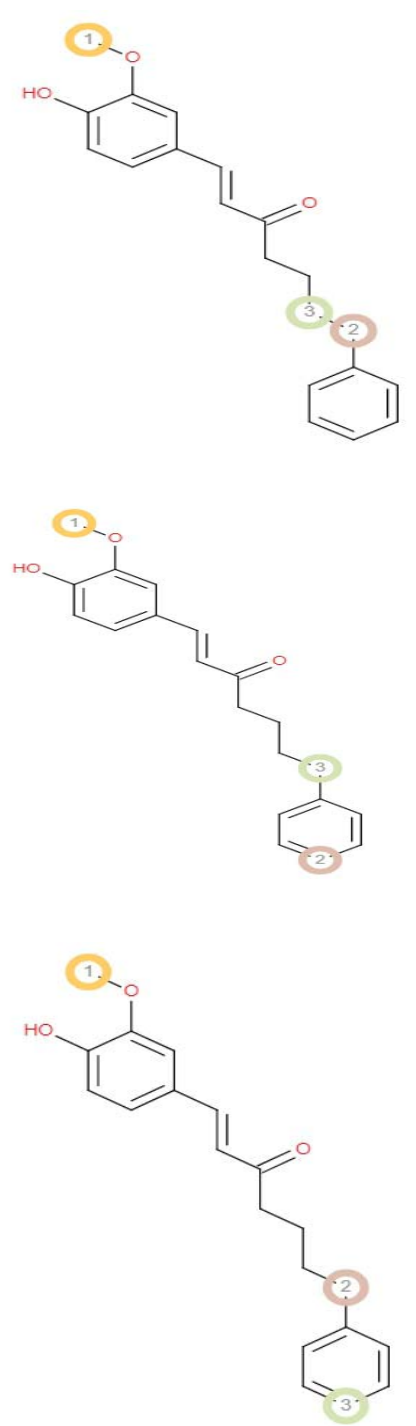

Figure 5: Results of P450 site of metabolism prediction. Best three vulnerable atoms are marked in encircled number.

\subsection{Analysis of Frontier's Orbitals}

Detailed HOMO energy, LUMO energy, energy gap (HOMO-LUMO gap), hardness and softness of the selected three compounds are summarized in Table $\mathbf{1 0}$ and the HOMO and LUMO occupation of the ligands is illustrated in Figure 6 for each compound. Highest gap was observed for 6-Gingerol and lowest gap was observed for Yakuchinone B. 
bioRxiv preprint doi: https://doi.org/10.1101/2020.01.27.921528; this version posted January 28, 2020. The copyright holder for this preprint

(which was not certified by peer review) is the author/funder, who has granted bioRxiv a license to display the preprint in perpetuity. It is made available under aCC-BY 4.0 International license.

\begin{tabular}{|c|c|c|c|c|c|c|}
\hline $\begin{array}{c}\text { Compound } \\
\text { Name }\end{array}$ & HOMO & LUMO & Gap & $\begin{array}{c}\text { Hardness } \\
\text { ( } \mathbf{n})\end{array}$ & $\begin{array}{c}\text { Softness } \\
(\mathbf{S})\end{array}$ & $\begin{array}{c}\text { Dipole } \\
\text { Moment }\end{array}$ \\
\hline 6-gingerol & -0.19924 & -0.01477 & 0.18447 & 0.09223 & 10.84167 & 3.3525 \\
\hline Yakuchinone A & -0.19952 & -0.01594 & 0.18358 & 0.09179 & 10.89443 & 2.1614 \\
\hline Yakuchinone B & -0.21682 & -0.05847 & 0.15835 & 0.07917 & 12.63104 & 4.5276 \\
\hline
\end{tabular}

Table 10: Result of DFT calculation. The unit of HOMO, LUMO, gap, hardness and softness are in Hartree and the unit of dipole moment is in Debye.

6-gingerol

Yakuchinone A

Yakuchinone B
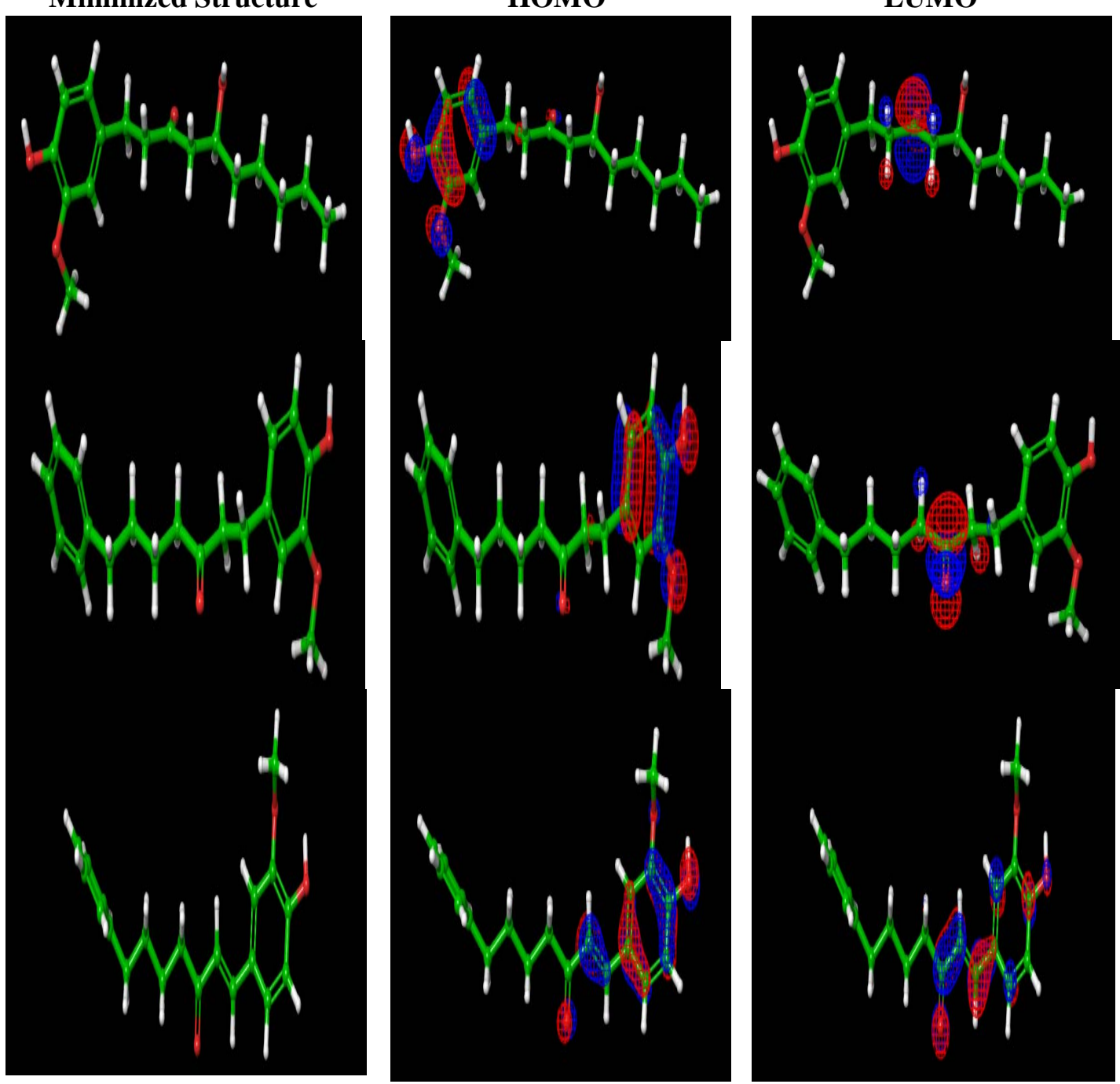

Figure 6: The HOMO and LUMO occupation for the selected compounds. Blue and red is positive and negative in its wave function. 
According to the energy gap the order of the compounds is: 6-Gingerol > Yakuchinone A> Yakuchinone B. Along with the HOMO and LUMO energy, Dipole moment of the selected ligand molecules were also calculated and according to dipole moment the order of compoiunds: Yakuchinone A > 6-Gingerol > Yakuchinone B.

\section{Discussions}

In silico analysis of drug likeness helps to filter out compounds with poor drug like potentials usually those have poor physicochemical properties. Violation of Lipinski's rule by a compound indicates that the compound is more likely to fail in the later trial [84][85]. In this experiment the ligand molecules were analyzed in accordance with Lipinski's rule of five. Cassumunin A and Cassumunin B violated the standard rule and then they were removed from consideration of further experiment (Table 3). Thereafter, 12 ligand molecules except these two were analyzed in the molecular docking experiment. Molecular docking is one of most commonly used tools in computer-aided drug designing. This tool works on specific algorithm which assigns binding energy after docking which in turn reflects binding affinity of a ligand to a molecular target [56][86][87]. Lowest binding energy of ligand-receptor complex reflects higher affinity meaning they remain more time in contact [88]. In this experiment SP and XP ligand docking were carried out to make comparison among docking parameters of different ligands. However, best three ligands for one receptor were selected based on MM-GBSA scoring because it is more rigorous scoring method (Table 4) [89][90]. Selected three ligands showed better binding free energies than approved inhibitors (control). Then the selected ligand molecules were subjected to induced fit docking (IFD) which is even powerful tool to generate poses and assigning scores [91]. Upon continuous exploration with different methods of molecular docking, 6-Gingerol, Yakuchinone A and Yakucinone B were selected as the best inhibitor of COX-2, IKK and TBK- 
1 respectively (Table 5 \& 6). Hydrogen bonding and hydrophobic interactions play significant role in strengthening the ligand receptor interactions [92]. All selected ligands were reported to form multiple hydrogen bonds and other forms of hydrophobic interactions inside the binding cleft of respective receptors (Figure 4).

In silico analysis of absorption, distribution, metabolism, excretion and toxicity is crucial to determine whether a drug is likely to survive in the later stages of drug development and these data again help to reduce the time and cost of drug discovery approach by assisting in vitro assays [71][93]. Blood brain barrier permeability is a major concern for the drugs targeting primarily the cells of central nervous system (CNS). Oral delivery system is the most commonly used route of drug delivery and the delivered drug migrates through the digestive tract into the intestine and so the drug under investigation is appreciated to be highly absorbed in human intestinal tissue. P-glycoproteins are the cell membrane glycoproteins that are responsible to facilitate the transport of many drugs through the cell membrane and hence their inhibition by candidate drugs may affect the normal drug transport inside human body. Caco2 permeability to drug reflects the human intestinal tissue permeability since this cell line is commonly used for in vitro permeability assay [94]-[96]. Cytochrome P450 family of enzymes is center to control the drug interaction, metabolism inside human body and excretion outside the body. Inhibition of these enzymes may lead to acute drug toxicity, slow clearance and eventually malfunction of the drug compound inside human body [97]-[99]. AMES toxicity approach is used to examine the toxicity endpoint of chemicals in question [100][101]. hERG (Human ether-a-go-go related gene) channels are the voltage gated potassium ion channels that play key roles for potassium ion transport through the cell membrane. Different structurally and functionally unrelated drugs have been reported to block the $h E R G$ potassium channel which has raised the concern of off-target 
drug interaction and so, screening compounds for activity on $h E R G$ channels early in the lead optimization process is crucial [102]. Renal OCT2 (organic cation transporter 2) is important for drug and xenobiotic excretion through kidney. The substrates of this transporter protein are considered to easily be excreted with urine [103]. All of the selected ligands exhibited almost similar properties in ADME/T test (Table 7).

Pharmacological activity (PASS prediction) is predicted in the context of probability of activity (Pa) and Probability of inactivity $(\mathrm{Pi})$ of a compound and the result of the prediction varies between 0.000 and 1.000. The activity is considered possible When $\mathrm{Pa}>\mathrm{Pi}[104]$. When $\mathrm{Pa}>0.7$, the compound is very likely to exhibit the activity but possibility of the compound being analogue to a known pharmaceutical is also high. Compound with $0.5<\mathrm{Pa}<0.7$ score is likely to exhibit the activity but the probability is less along with the chance of being a known pharmaceutical agent is also lower. When $\mathrm{Pa}<0.5$, then the compound is less likely to exhibit the activity [105]. Pharmacological activity was predicted for the compounds against antiinflammatory activity and other proteins, transcription factors, enzymes and cytokines involved in different inflammatory cascades. Yakuchinone B performed slightly better almost overall all the ligands were predicted to have similar activities (Table 8). Then the ligands were analyzed for their potential biological activities against GPCRs ( $G$ protein coupled receptors), ion channels, enzymes, nuclear receptors etc. which are the most potent drug targets in human body. Only GPCRS are the targets of 50\% of currently available drugs in the market [106]-[108]. The ligands showed significant connections (probability scores) against all targets which might be useful for drug discovery expenditure but at the same time could also raise concern of unpleasant drug-target interaction as useless (Table 9). 
Then the ligands were analyzed for their potential metabolism sites for three major enzymes i.e., CYP3A4, CYP2D6 and CYP2C9 of Cytochrome P450 family and multiple sites for each molecules were recorded (Figure 5). The best ligands were also analyzed for their HOMO and LUMO energy and occupation. HOMO is usually a constraint portion in a molecule that is capable of donating electrons whereas LUMO is responsible for accepting electrons (Figure 6). HOMO-LUMO gap is used to define the stability of a compound. A compound having highest gap is likely to undergo a chemical reaction more easily [109][110]. Yakuchinone A and 6Gingerol showed almost similar energy gap whereas Yakuchinone B showed slightly lower gap (Table 10).

Finally, 6-Gingerol, Yakuchinone A and Yakuchinone B were the best findings of this study. Anti-inflammatory activities of these compounds have already been proven in laboratory experiments [111]-[113]. These compounds also performed quite similar in different postscreening study after docking experiment which could be useful for further drug discovery approach. However, these findings might be required to be supported by further in vitro study.

Overall, this study recommends 6-Gingerol, Yakuchinone A and Yakuchinone B as the best inhibitors of COX-2, IKK and TBK-1 respectively among the selected curcumin analogues although other compounds can also be investigated since they also performed well in docking experiment.

\section{Conclusion}

In this study 14 Curcumin analogues were utilized to explore their anti-inflammatory activities against three signaling proteins in the TLR4 pathway. Upon continuous computational exploration 6-Gingerol, Yakuchinone A and Yakuchinone B were identified as the best agents 
having inhibitory effects on COX-2, IKK and TBK-1 respectively. Their drug like potentials were also analyzed and they were found to have sound and similar drug like parameters. Therefore, these compounds could be considered as potential anti-inflammatory agents in the search for new medication against inflammation. However, authors suggest further in vitro study with these compounds to confirm their anti-inflammatory activities and strengthen these findings.

\section{Conflict of Interest}

Authors declare no conflict of interest regarding the publication of the manuscript.

\section{Data Availability Statement}

Authors made all the data generated during experiment and analysis available within the manuscript.

\section{Funding Statement}

Authors received no specific funding from any external sources.

\section{Acknowledgements}

Authors acknowledge the members of Swift Integrity Computational Lab, Dhaka, Bangladesh, a virtual platform of young researchers for their support during the preparation of the manuscript.

\section{References}

1. Ricciotti E, FitzGerald GA. Prostaglandins and inflammation. Arteriosclerosis, thrombosis, and vascular biology. 2011 May;31(5):986-1000.

2. Liu CH, Abrams ND, Carrick DM, Chander P, Dwyer J, Hamlet MR, Kindzelski AL, 
PrabhuDas M, Tsai SY, Vedamony MM, Wang C. Imaging inflammation and its resolution in health and disease: current status, clinical needs, challenges, and opportunities. The FASEB Journal. 2019 Dec;33(12):13085-97.

3. Medzhitov R. Origin and physiological roles of inflammation. Nature. 2008 Jul;454(7203):428-35.

4. Lon HK, Liu D, Jusko WJ. Pharmacokinetic/pharmacodynamic modeling in inflammation. Critical Reviews ${ }^{\mathrm{TM}}$ in Biomedical Engineering. 2012;40(4).

5. Horadagoda NU, Knox KM, Gibbs HA, Reid SW, Horadagoda A, Edwards SE, Eckersall PD. Acute phase proteins in cattle: discrimination between acute and chronic inflammation. Veterinary Record. 1999 Apr 17;144(16):437-41.

6. Lee JW, Lee YK, Yuk DY, Choi DY, Ban SB, Oh KW, Hong JT. Neuro-inflammation induced by lipopolysaccharide causes cognitive impairment through enhancement of betaamyloid generation. Journal of neuroinflammation. 2008 Dec 1;5(1):37.

7. Feghali CA, Wright TM. Cytokines in acute and chronic inflammation. Front Biosci. 1997 Jan $1 ; 2(1): \mathrm{d} 12-26$.

8. Cox SS, Speaker KJ, Beninson LA, Craig WC, Paton MM, Fleshner M. Adrenergic and glucocorticoid modulation of the sterile inflammatory response. Brain, behavior, and immunity. 2014 Feb 1;36:183-92.

9. Libby P. Inflammation and cardiovascular disease mechanisms. The American journal of clinical nutrition. 2006 Feb 1;83(2):456S-60S.

10. Coussens LM, Werb Z. Inflammation and cancer. Nature. 2002 Dec;420(6917):860-7. 
11. Zvaifler NJ. The immunopathology of joint inflammation in rheumatoid arthritis. InAdvances in immunology 1973 Jan 1 (Vol. 16, pp. 265-336). Academic Press.

12. Bauer ME, Teixeira AL. Inflammation in psychiatric disorders: what comes first?. Annals of the New York Academy of Sciences. 2019 Feb;1437(1):57-67.

13. Kaczorowski DJ, Nakao A, Vallabhaneni R, Mollen KP, Sugimoto R, Kohmoto J, Zuckerbraun BS, McCurry K, Billiar TR. Mechanisms of Toll-like receptor 4 (TLR4)-mediated inflammation after cold ischemia/reperfusion in the heart. Transplantation. 2009 May 27;87(10):1455.

14. Blackwell TS, Christman JW. The role of nuclear factor- $\kappa$ B in cytokine gene regulation. American journal of respiratory cell and molecular biology. 1997 Jul 1;17(1):3-9.

15. Zhang B, Ramesh G, Uematsu S, Akira S, Reeves WB. TLR4 signaling mediates inflammation and tissue injury in nephrotoxicity. Journal of the American Society of Nephrology. 2008 May 1;19(5):923-32..

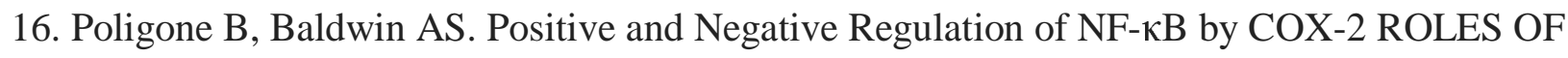
DIFFERENT PROSTAGLANDINS. Journal of Biological Chemistry. 2001 Oct $19 ; 276(42): 38658-64$.

17. Fitzgerald KA, McWhirter SM, Faia KL, Rowe DC, Latz E, Golenbock DT, Coyle AJ, Liao SM, Maniatis T. IKK $\varepsilon$ and TBK1 are essential components of the IRF3 signaling pathway. Nature immunology. 2003 May;4(5):491-6.

18. Tak PP, Firestein GS. NF-кB: a key role in inflammatory diseases. The Journal of clinical investigation. 2001 Jan 1;107(1):7-11. 
19. Zhao P, in Wong K, Sun X, Reilly SM, Uhm M, Liao Z, Skorobogatko Y, Saltiel AR. TBK1 at the crossroads of inflammation and energy homeostasis in adipose tissue. Cell. 2018 Feb $8 ; 172(4): 731-43$.

20. Kishore N, Huynh QK, Mathialagan S, Hall T, Rouw S, Creely D, Lange G, Caroll J, Reitz B, Donnelly A, Boddupalli H. IKK-i and TBK-1 are Enzymatically Distinct from the Homologous Enzyme IKK-2 COMPARATIVE ANALYSIS OF RECOMBINANT HUMAN IKK-i, TBK-1, AND IKK-2. Journal of Biological Chemistry. 2002 Apr 19;277(16):13840-7.

21. Yu M, Ives D, Ramesha CS. Synthesis of prostaglandin E2 ethanolamide from anandamide by cyclooxygenase-2. Journal of Biological Chemistry. 1997 Aug 22;272(34):21181-6.

22. Hasan M, Yan N. Therapeutic potential of targeting TBK1 in autoimmune diseases and interferonopathies. Pharmacological research. 2016 Sep 1;111:336-42.

23. Burke JR, Pattoli MA, Gregor KR, Brassil PJ, MacMaster JF, McIntyre KW, Yang X, Iotzova VS, Clarke W, Strnad J, Qiu Y. BMS-345541 is a highly selective inhibitor of IкB kinase that binds at an allosteric site of the enzyme and blocks NF- $\kappa \mathrm{B}$-dependent transcription in mice. Journal of Biological Chemistry. 2003 Jan 17;278(3):1450-6.

24. Voilley N, de Weille J, Mamet J, Lazdunski M. Nonsteroid anti-inflammatory drugs inhibit both the activity and the inflammation-induced expression of acid-sensing ion channels in nociceptors. Journal of Neuroscience. 2001 Oct 15;21(20):8026-33.

25. I. Bjarnason, J. Hayllar, A. N. dre. J. Macpherson, and A. N. thon. S. Russell, "Side effects of nonsteroidal anti-inflammatory drugs on the small and large intestine in humans,"

Gastroenterology, vol. 104, no. 6, pp. 1832-1847, 1993. 
26. Mendes RT, Stanczyk CP, Sordi R, Otuki MF, dos Santos FA, Fernandes D. Selective inhibition of cyclooxygenase-2: risks and benefits. Rev Bras Reumatol. 2012 Oct;52(5):767-82.

27. Rao P, Knaus EE. Evolution of nonsteroidal anti-inflammatory drugs (NSAIDs):

cyclooxygenase (COX) inhibition and beyond. Journal of Pharmacy \& Pharmaceutical Sciences. 2008 Sep 20;11(2):81-110s.

28. Martel-Pelletier J, Lajeunesse D, Reboul P, Pelletier JP. Therapeutic role of dual inhibitors of 5-LOX and COX, selective and non-selective non-steroidal anti-inflammatory drugs. Annals of the rheumatic diseases. 2003 Jun 1;62(6):501-9.

29. Payne R. Limitations of NSAIDs for pain management: toxicity or lack of efficacy?. The Journal of Pain. 2000 Sep 1;1(3):14-8.

30. Lisowska B, Kosson D, Domaracka K. Positives and negatives of nonsteroidal antiinflammatory drugs in bone healing: the effects of these drugs on bone repair. Drug design, development and therapy. 2018;12:1809.

31. De Gaetano G, Donati MB, Cerletti C. Prevention of thrombosis and vascular inflammation: benefits and limitations of selective or combined COX-1, COX-2 and 5-LOX inhibitors. Trends in pharmacological sciences. 2003 May 1;24(5):245-52.

32. Asenso J, Yang XD, Yu J, Zhou P, Wang C, Wei W. Plant-based anti-inflammatory agents: Progress from Africa and China. Clinical anti-Inflammatory \& anti-Allergy Drugs. 2015 Apr $1 ; 2(1): 52-66$.

33. Sarkar B, Ullah MA, Islam MS, Hossain S, Nafi-Ur-Rahman M. Anticancer potential of medicinal plants from Bangladesh and their effective compounds against cancer. Journal of 
Pharmacognosy and Phytochemistry. 2019;8(3):827-33.

34. Maione F, Russo R, Khan H, Mascolo N. Medicinal plants with anti-inflammatory activities. Natural product research. 2016 Jun 17;30(12):1343-52.

35. Goel A, Boland CR, Chauhan DP. Specific inhibition of cyclooxygenase-2 (COX-2) expression by dietary curcumin in HT-29 human colon cancer cells. Cancer letters. 2001 Oct 30;172(2):111-8.

36. Kohli K, Ali J, Ansari MJ, Raheman Z. Curcumin: a natural antiinflammatory agent. Indian Journal of Pharmacology. 2005 May 1;37(3):141.

37. Meng Z, Yan C, Deng Q, Gao DF, Niu XL. Curcumin inhibits LPS-induced inflammation in

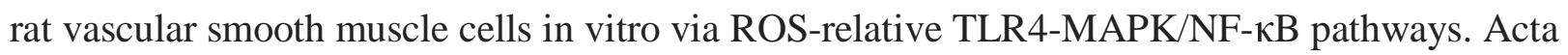
Pharmacologica Sinica. 2013 Jul;34(7):901-11.

38. Zhu HT, Bian C, Yuan JC, Chu WH, Xiang X, Chen F, Wang CS, Feng H, Lin JK. Curcumin attenuates acute inflammatory injury by inhibiting the TLR4/MyD88/NF- $\kappa$ B signaling pathway in experimental traumatic brain injury. Journal of neuroinflammation. 2014 Dec 1;11(1):59.

39. Yuniarti N, Nugroho PA, Asyhar A, Sardjiman S, Ikawati Z, Istyastono EP. In vitro and In Silico Studies on Curcumin and Its Analogues as Dual Inhibitors for cyclooxygenase-1 (COX-1) and cyclooxygenase-2 (COX-2). Journal of Mathematical and Fundamental Sciences. 2012;44(1):51-66.

40. Shishodia S, Potdar P, Gairola CG, Aggarwal BB. Curcumin (diferuloylmethane) downregulates cigarette smoke-induced NF- $\kappa \mathrm{B}$ activation through inhibition of $\mathrm{I} \kappa \mathrm{B} \alpha$ kinase in human lung epithelial cells: correlation with suppression of COX-2, MMP-9 and cyclin D1. 
Carcinogenesis. 2003 Jul 1;24(7):1269-79.

41. Chun KS, Kang JY, Kim OH, Kang H, Surh YJ. Effects of yakuchinone A and yakuchinone B on the Phorbol ester-induced expression of COX-2 and iNOS and activation of NF-kB in mouse skin. Journal of environmental pathology, toxicology and oncology. 2002;21(2).

42. Simerska P, Moyle PM, Toth I. Modern lipid $\square$, carbohydrate $\square$, and peptide $\square$ based delivery systems for peptide, vaccine, and gene products. Medicinal research reviews. 2011 Jul;31(4):520-47.

43. Park SJ, Lee MY, Son BS, Youn HS. TBK1-targeted suppression of TRIF-dependent signaling pathway of Toll-like receptors by 6-shogaol, an active component of ginger.

Bioscience, biotechnology, and biochemistry. 2009 Jul 23;73(7):1474-8.

44. Anand P, Thomas SG, Kunnumakkara AB, Sundaram C, Harikumar KB, Sung B, Tharakan ST, Misra K, Priyadarsini IK, Rajasekharan KN, Aggarwal BB. Biological activities of curcumin and its analogues (Congeners) made by man and Mother Nature. Biochemical pharmacology. 2008 Dec 1;76(11):1590-611.

45. Kiuchi F, Goto Y, Sugimoto N, AKAO N, KONDO K, TSUDA Y. Nematocidal activity of turmeric: synergistic action of curcuminoids. Chemical and Pharmaceutical Bulletin. 1993 Sep 15;41(9):1640-3.

46. Kim SO, Kundu JK, Shin YK, Park JH, Cho MH, Kim TY, Surh YJ. [6]-Gingerol inhibits COX-2 expression by blocking the activation of p38 MAP kinase and NF- $\kappa$ B in phorbol esterstimulated mouse skin. Oncogene. 2005 Apr;24(15):2558-67.

47.Huang WY, Cai YZ, Zhang Y. Natural phenolic compounds from medicinal herbs and dietary 
plants: potential use for cancer prevention. Nutrition and cancer. 2009 Dec 31;62(1):1-20.

48. Keum YS, Kim J, Lee KH, Park KK, Surh YJ, Lee JM, Lee SS, Yoon JH, Joo SY, Cha IH, Yook JI. Induction of apoptosis and caspase-3 activation by chemopreventive [6]-paradol and structurally related compounds in KB cells. Cancer letters. 2002 Mar 8;177(1):41-7.

49. Ling H, Yang H, Tan SH, Chui WK, Chew EH. $6 \square$ Shogaol, an active constituent of ginger, inhibits breast cancer cell invasion by reducing matrix metalloproteinase $\square 9$ expression via blockade of nuclear factor $\square$ ผB activation. British journal of pharmacology. 2010 Dec;161(8):1763-77.

50. Masuda T, Matsumura H, Oyama Y, Takeda Y, Jitoe A, Kida A, Hidaka K. Synthesis of ( \pm )cassumunins A and B, new curcuminoid antioxidants having protective activity of the living cell against oxidative damage. Journal of natural products. 1998 May 22;61(5):609-13.

51. Yogosawa S, Yamada Y, Yasuda S, Sun Q, Takizawa K, Sakai T. Dehydrozingerone, a structural analogue of curcumin, induces cell-cycle arrest at the G2/M phase and accumulates intracellular ROS in HT-29 human colon cancer cells. Journal of natural products. 2012 Dec $28 ; 75(12): 2088-93$.

52. Anand P, Sung B, Kunnumakkara AB, Rajasekharan KN, Aggarwal BB. RETRACTED: Suppression of pro-inflammatory and proliferative pathways by diferuloylmethane (curcumin) and its analogues dibenzoylmethane, dibenzoylpropane, and dibenzylideneacetone: Role of Michael acceptors and Michael donors.

53. FUJISAWA S, ATSUMI T, ISHIHARA M, KADOMA Y. Cytotoxicity, ROS-generation activity and radical-scavenging activity of curcumin and related compounds. Anticancer research. 2004 Mar 1;24(2B):563-70. 
54. Flynn DL, Rafferty MF, Boctor AM. Inhibition of 5-hydroxy-eicosatetraenoic acid (5-HETE) formation in intact human neutrophils by naturally-occurring diarylheptanoids: inhibitory activities of curcuminoids and yakuchinones. Prostaglandins, Leukotrienes and Medicine. 1986 Jun 1;22(3):357-60.

55. Lipinski CA, Lombardo F, Dominy BW, Feeney PJ. Experimental and computational approaches to estimate solubility and permeability in drug discovery and development settings. Advanced drug delivery reviews. 1997 Jan 15;23(1-3):3-25.

56. Ullah A, Prottoy NI, Araf Y, Hossain S, Sarkar B, Saha A. Molecular Docking and Pharmacological Property Analysis of Phytochemicals from Clitoria ternatea as Potent Inhibitors of Cell Cycle Checkpoint Proteins in the Cyclin/CDK Pathway in Cancer Cells. Computational Molecular Bioscience. 2019 Sep 6;9(03):81.

57. Bolton EE, Wang Y, Thiessen PA, Bryant SH. PubChem: integrated platform of small molecules and biological activities. InAnnual reports in computational chemistry 2008 Jan 1 (Vol. 4, pp. 217-241). Elsevier.

58. Cheminformatics, M., 2014. Bratislava, Slovak Republic.

59. Lucido MJ, Orlando BJ, Vecchio AJ, Malkowski MG. Crystal structure of aspirin-acetylated human cyclooxygenase-2: insight into the formation of products with reversed stereochemistry. Biochemistry. 2016 Mar 1;55(8):1226-38.

60. Xu G, Lo YC, Li Q, Napolitano G, Wu X, Jiang X, Dreano M, Karin M, Wu H. Crystal structure of inhibitor of $\kappa \mathrm{B}$ kinase $\beta$. Nature. 2011 Apr;472(7343):325-30. 
61. Beyett TS, Gan X, Reilly SM, Chang L, Gomez AV, Saltiel AR, Showalter HD, Tesmer JJ. Carboxylic acid derivatives of amlexanox display enhanced potency toward TBK1 and IKKE and reveal mechanisms for selective inhibition. Molecular pharmacology. 2018 Oct 1;94(4):1210-9.

62. Schrödinger Release 2018-4: Protein Preparation Wizard; Epik, Schrödinger, LLC, New York, NY, 2016; Impact, Schrödinger, LLC, New York, NY, 2016; Prime, Schrödinger, LLC, New York, NY, 2018.

63. Kim S, Thiessen PA, Bolton EE, Chen J, Fu G, Gindulyte A, Han L, He J, He S, Shoemaker BA, Wang J. PubChem substance and compound databases. Nucleic acids research. 2016 Jan 4;44(D1):D1202-13.

64. Schrödinger Release 2018-4: LigPrep, Schrödinger, LLC, New York, NY, 2018.

65. Schrödinger Release 2018-4: Glide, Schrödinger, LLC, New York, NY, 2018.

66. Ramírez D, Caballero J. Is it reliable to use common molecular docking methods for comparing the binding affinities of enantiomer pairs for their protein target?. International journal of molecular sciences. 2016 Apr;17(4):525.

67. Dassault Systèmes BIOVIA, Discovery Studio Visualizer, 19.1, San Diego: Dassault Systèmes, 2019.

68. Lyne PD, Lamb ML, Saeh JC. Accurate prediction of the relative potencies of members of a series of kinase inhibitors using molecular docking and MM-GBSA scoring. Journal of medicinal chemistry. 2006 Aug 10;49(16):4805-8. 
69. Wishart DS, Knox C, Guo AC, Cheng D, Shrivastava S, Tzur D, Gautam B, Hassanali M. DrugBank: a knowledgebase for drugs, drug actions and drug targets. Nucleic acids research. 2008 Jan 1;36(suppl_1):D901-6.

70. Zhong H, Tran LM, Stang JL. Induced-fit docking studies of the active and inactive states of protein tyrosine kinases. Journal of Molecular Graphics and Modelling. 2009 Nov 1;28(4):33646.

71. $\mathrm{Yu} \mathrm{H}$, Adedoyin A. ADME-Tox in drug discovery: integration of experimental and computational technologies. Drug discovery today. 2003 Sep 15;8(18):852-61.

72. Hossain S, Sarkar B, Prottoy MN, Araf Y, Taniya MA, Ullah MA. Thrombolytic Activity, Drug Likeness Property and ADME/T Analysis of Isolated Phytochemicals from Ginger (Zingiber officinale) Using In Silico Approaches. Modern Research in Inflammation. 2019 Aug $31 ; 8(3): 29-43$.

73. Yang H, Lou C, Sun L, Li J, Cai Y, Wang Z, Li W, Liu G, Tang Y. admetSAR 2.0: webservice for prediction and optimization of chemical ADMET properties. Bioinformatics. 2019 Mar 15;35(6):1067-9.

74. Pires DE, Blundell TL, Ascher DB. pkCSM: predicting small-molecule pharmacokinetic and toxicity properties using graph-based signatures. Journal of medicinal chemistry. 2015 May 14;58(9):4066-72.

75. Filimonov DA, Lagunin AA, Gloriozova TA, Rudik AV, Druzhilovskii DS, Pogodin PV, Poroikov VV. Prediction of the biological activity spectra of organic compounds using the PASS online web resource. Chemistry of Heterocyclic Compounds. 2014 Jun 1;50(3):444-57. 
76. Tarcsay Á, Keserü GM. In silico site of metabolism prediction of cytochrome P450-mediated biotransformations. Expert opinion on drug metabolism \& toxicology. 2011 Mar 1;7(3):299-312.

77. Zaretzki J, Bergeron C, Huang TW, Rydberg P, Swamidass SJ, Breneman CM. RSWebPredictor: a server for predicting CYP-mediated sites of metabolism on drug-like molecules. Bioinformatics. 2013 Feb 15;29(4):497-8.

78. Schrödinger Release 2018-4: Jaguar, Schrödinger, LLC, New York, NY, 2018.

79. Becke AD. A new mixing of Hartree-Fock and local density $\square$ functional theories. The Journal of chemical physics. 1993 Jan 15;98(2):1372-7.

80. Gill PM, Johnson BG, Pople JA, Frisch MJ. The performance of the Becke-Lee-YangParr (B-LYP) density functional theory with various basis sets. Chemical Physics Letters. 1992 Sep 18;197(4-5):499-505.

81. Stephens PJ, Devlin FJ, Chabalowski CF, Frisch MJ. Ab initio calculation of vibrational absorption and circular dichroism spectra using density functional force fields. The Journal of physical chemistry. 1994 Nov;98(45):11623-7.

82. Pearson RG. Absolute electronegativity and hardness correlated with molecular orbital theory. Proceedings of the National Academy of Sciences. 1986 Nov 1;83(22):8440-1.

83. Parr RG. Density functional theory of atoms and molecules. InHorizons of Quantum Chemistry 1980 (pp. 5-15). Springer, Dordrecht.

84. Tian S, Wang J, Li Y, Li D, Xu L, Hou T. The application of in silico drug-likeness predictions in pharmaceutical research. Advanced drug delivery reviews. 2015 Jun 23;86:2-10.

85. Sarkar B, Islam SS, Ullah MA, Hossain S, Prottoy MN, Araf Y, Taniya MA. Computational Assessment and Pharmacological Property Breakdown of Eight Patented and Candidate Drugs 
against Four Intended Targets in Alzheimer's Disease. Advances in Bioscience and Biotechnology. 2019 Nov 25;10(11):405.

86. Gschwend DA, Good AC, Kuntz ID. Molecular docking towards drug discovery. Journal of Molecular Recognition: An Interdisciplinary Journal. 1996 Mar;9(2):175-86.

87. Prottoy NI, Sarkar B, Ullah A, Hossain S, Boby AS, Araf Y. Molecular Docking and Pharmacological Property Analysis of Antidiabetic Agents from Medicinal Plants of Bangladesh against Type II Diabetes: A Computational Approach. PharmaTutor. 2019 Sep 1;7(9):6-15.

88. Shoichet BK, McGovern SL, Wei B, Irwin JJ. Lead discovery using molecular docking. Current opinion in chemical biology. 2002 Aug 1;6(4):439-46.

89. Sarkar B, Ullah MA, Islam SS. In Silico Analysis of Some Phytochemicals as Potential Anticancer Agents Targeting Cyclin Dependent Kinase-2, Human Topoisomerase IIa and Vascular Endothelial Growth Factor Receptor-2. bioRxiv. 2020 Jan 1.

90. Sun H, Li Y, Tian S, Xu L, Hou T. Assessing the performance of MM/PBSA and MM/GBSA methods. 4. Accuracies of MM/PBSA and MM/GBSA methodologies evaluated by various simulation protocols using PDBbind data set. Physical Chemistry Chemical Physics. 2014;16(31):16719-29.

91. Tripathi A, Bankaitis VA. Molecular docking: From lock and key to combination lock. Journal of molecular medicine and clinical applications. 2017;2(1).

92. Davis AM, Teague SJ. Hydrogen bonding, hydrophobic interactions, and failure of the rigid receptor hypothesis. Angewandte Chemie International Edition. 1999 Mar 15;38(6):736-49.

93. Wang Y, Xing J, Xu Y, Zhou N, Peng J, Xiong Z, Liu X, Luo X, Luo C, Chen K, Zheng M. In silico ADME/T modelling for rational drug design. Quarterly reviews of biophysics. 2015 Nov;48(4):488-515. 
94. Paul Gleeson M, Hersey A, Hannongbua S. In-silico ADME models: a general assessment of their utility in drug discovery applications. Current topics in medicinal chemistry. 2011 Feb $1 ; 11(4): 358-81$.

95. Li AP. Screening for human ADME/Tox drug properties in drug discovery. Drug discovery today. 2001 Apr 1;6(7):357-66.

96. Geerts T, Vander Heyden Y. In silico predictions of ADME-Tox properties: drug absorption. Combinatorial chemistry \& high throughput screening. 2011 Jun 1;14(5):339-61.

97. Anzenbacher P, Anzenbacherova E. Cytochromes P450 and metabolism of xenobiotics. Cellular and Molecular Life Sciences CMLS. 2001 May 1;58(5-6):737-47.

98. Lamb DC, Waterman MR, Kelly SL, Guengerich FP. Cytochromes P450 and drug discovery. Current opinion in biotechnology. 2007 Dec 1;18(6):504-12.

99. De Graaf C, Vermeulen NP, Feenstra KA. Cytochrome P450 in silico: an integrative modeling approach. Journal of medicinal chemistry. 2005 Apr 21;48(8):2725-55.

100. Ames BN, Gurney EG, Miller JA, Bartsch H. Carcinogens as frameshift mutagens: metabolites and derivatives of 2-acetylaminofluorene and other aromatic amine carcinogens. Proceedings of the National Academy of Sciences. 1972 Nov 1;69(11):3128-32.

101. Xu C, Cheng F, Chen L, Du Z, Li W, Liu G, Lee PW, Tang Y. In silico prediction of chemical Ames mutagenicity. Journal of chemical information and modeling. 2012 Nov 26;52(11):2840-7.

102. Priest B, Bell IM, Garcia M. Role of hERG potassium channel assays in drug development. Channels. 2008 Mar 5;2(2):87-93. 
103. Hacker K, Maas R, Kornhuber J, Fromm MF, Zolk O. Substrate-dependent inhibition of the human organic cation transporter OCT2: a comparison of metformin with experimental substrates. PloS one. 2015;10(9).

104. Stepanchikova AV, Lagunin AA, Filimonov DA, Poroikov VV. Prediction of biological activity spectra for substances: Evaluation on the diverse sets of drug-like structures. Current medicinal chemistry. 2003 Feb 1;10(3):225-33.

105. Lagunin A, Stepanchikova A, Filimonov D, Poroikov V. PASS: prediction of activity spectra for biologically active substances. Bioinformatics. 2000 Aug 1;16(8):747-8.

106. Overington JP, Al-Lazikani B, Hopkins AL. How many drug targets are there?. Nature reviews Drug discovery. 2006 Dec;5(12):993-6.

107. Lundstrom K. An overview on GPCRs and drug discovery: structure-based drug design and structural biology on GPCRs. InG Protein-Coupled Receptors in Drug Discovery 2009 (pp. 5166). Humana Press, Totowa, NJ.

108. Mainardes RM, Silva LP. Drug delivery systems: past, present, and future. Current drug targets. 2004 Jul 1;5(5):449-55.

109. Zhan CG, Nichols JA, Dixon DA. Ionization potential, electron affinity, electronegativity, hardness, and electron excitation energy: molecular properties from density functional theory orbital energies. The Journal of Physical Chemistry A. 2003 May 22;107(20):4184-95.

110. Becke AD. Density-functional exchange-energy approximation with correct asymptotic behavior. Physical review A. 1988 Sep 1;38(6):3098. 
111. Young HY, Luo YL, Cheng HY, Hsieh WC, Liao JC, Peng WH. Analgesic and antiinflammatory activities of [6]-gingerol. Journal of ethnopharmacology. 2005 Jan 4;96(1-2):207-

10.

112. Chun KS, Kang JY, Kim OH, Kang H, Surh YJ. Effects of yakuchinone A and yakuchinone B on the Phorbol ester-induced expression of COX-2 and iNOS and activation of NF-kB in mouse skin. Journal of environmental pathology, toxicology and oncology. 2002;21(2).

113. Chun KS, Park KK, Lee J, Kang M, Surh YJ. Inhibition of mouse skin tumor promotion by anti-inflammatory diarylheptanoids derived from Alpinia oxyphylla Miquel (Zingiberaceae). Oncology Research Featuring Preclinical and Clinical Cancer Therapeutics. 2002 Jan 1;13(1):3745. 